Linköping Studies in Science and Technology

Licentiate Thesis No. 1807

\title{
Influencing anaerobic digestion early stage processes for increased biomethane production from different substrate components
}

\author{
Anna Odnell
}

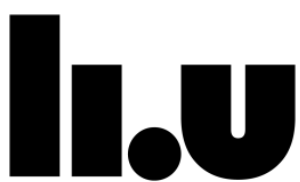

LINKÖPING UNIVERSITY

\author{
Department of Physics, Chemistry and Biology \\ Linköping University, Sweden
}

Linköping 2018 
Cover: Result from biochemical methane potential test from paper I.

During the course of the research underlying this thesis, Anna Odnell was affiliated to the Linköping University Biogas Research Center (LiU-BRC) financed by the Swedish Energy Agency, Linköping University and biogas industry partners and members of LiU-BRC.

(C) Copyright 2018 Anna Odnell, unless otherwise noted

Published articles and figures have been reprinted with permission from the publishers.

Paper I (C) 2013 Elsevier

Paper II (C) 2016 Elsevier

Paper III @ 2017 Springer

Odnell, Anna

Influencing anaerobic digestion early stage processes for increased biomethane production from different substrate components

ISBN: 978-91-7685-286-6

ISSN: 0280-7971

Linköping Studies in Science and Technology, Licentiate Thesis No. 1807

Electronic publication: http://www.ep.liu.se

Printed by LiU-Tryck, Linköping, Sweden, 2018 
Just do it 


\begin{abstract}
Finding alternatives to petroleum-based energy sources is of interest since it could reduce the emissions of net carbon dioxide to the atmosphere by increasing the usage of renewable energy sources. To do so improvements are needed in the renewable energy production sector. Biogas production is of interest since the anaerobic digestion process can degrade many different biomolecules and is, contrary to e.g. bioethanol and biodiesel, not dependent on specific molecules. Thus, many wastes such as slaughterhouse waste, sludge from waste water treatment and lignocellulose residual material etc. can be used as substrates for biogas production. However, there are limitations in the degradation process depending on the composition of the selected substrate. To overcome these limitations such as inhibition of different microorganisms, or recalcitrant substrate, different methods can be used to increase the biogas production.
\end{abstract}

In this study different substrates were selected and analyzed/treated for remedies of early stage rate limiting problems of the anaerobic digestion process. Different analyzes and techniques were selected depending on the limitations correlated to the main problematic component of the specific substrate.

Improvements could be reached for the degradation of slaughterhouse waste by augmentation with the clay mineral zeolite. Addition of different enzymes to the substrate environment of different waste water treatment plant sludges resulted in limited life time of the selected enzymes. However, certain enzymes proved to be promising candidates with an effect of increased biogas production rate and yield for the time that the enzyme remained active. In an additional experiment, cellulolytic enzymes, naturally produced by a biogas producing microbial community, were induced, collected and added to a biogas experiment of ensiled forage ley, by which it was shown that these cellulases led to an increase in biogas production rate and yield. Thus, the studies demonstrate different techniques for improving the anaerobic digestion process of different types of substrates. 


\section{Populärvetenskaplig sammanfattning}

I dagens konsumtionssamhälle förbrukar vi resurser som aldrig förr. För att vi ska kunna lämna jorden och dess resurser till framtida generationer behöver vi förbättra möjligheterna att kunna leva hållbart och utnyttja de resurser och restprodukter som finns på ett effektivt sätt. Vi använder idag icke förnyelsebar energi till stor del trots att det finns flera alternativ. Ett förnyelsebart alternativ är biogas. Biogas kan användas för att producera elektricitet, värme eller till och med uppgraderas för att producera fordonsbränsle. Under 2016 producerades det biometan motsvarande $2018 \mathrm{GWh}$ vid biogasanläggningar i Sverige. Det motsvarar energianvändningen för cirka 100000 svenska hushåll under ett år (baserat på en energiförbrukning om $20000 \mathrm{kWh} / a ̊ r)$. Om det vore möjligt att finna sätt att förbättra biogasproduktionen från substrat där det idag finns begränsningar skulle det vara till en stor nytta för samhället.

I arbetet har substrat med olika begränsningar i det tidiga stadiet av biogasprocessen undersökts med syfte att finna förbättringar. Det har kunnat konstateras att nedbrytning av slakteriavfall kan ske effektivare och snabbare tack vare tillsatts av mineralet zeolit. Tillsats av enzymer (biologiska katalysatorer) har även kunnat förbättra biogasutbytet för slam från reningsverk men även för ensilerad vall. Studien visar att det finns olika tekniker för att förbättra biogasprocessen beroende på vilka substrat som används och beroende på vilka begränsningar som kommer med det specifika substratet. 


\section{List of publications}

This thesis is based on the following papers, which are referred to in the text by their Roman numerals (I-III).

I Nordell, E., Hansson, AB., Karlsson, M. (2013). Zeolites relieves inhibitory stress from high concentrations of long chain fatty acids. Waste Management, 33, 2659-2663.

II Odnell, A., Recktenwald, M., Stensén, K., Jonsson B.-H., Karlsson, M. (2016). Activity, life time and effect of hydrolytic enzymes for enhanced biogas production from sludge anaerobic digestion. Water Research, 103, 462-471

III Speda J., Johansson M.A., Odnell A., Karlsson M. (2017). Enhanced biomethane production rate and yield from lignocellulosic ensiled forage ley by in situ anaerobic digestion treatment with endogenous cellulolytic enzymes. Biotechnology for Biofuels. 10:129 


\section{Contribution report}

I Anna Odnell (AO) was involved in all planning and performed the majority of the experiments, contributed to the interpretation of the results and co-authored the manuscript.

II $\quad \mathrm{AO}$ planned the majority of the experimental work and carried out all experiments, performed the majority of results interpretation and wrote the majority of the manuscript.

III AO was involved in the design and execution of the biochemical methane potential (BMP) studies of lignocellulose, contributed to the $\mathrm{BMP}$ results interpretation and co-authored the manuscript. 


\section{Conference contributions}

Nordell, E., Hansson, A., Karlsson, M. (2012). Zeolites relieves inhibitory stress from high concentrations of long chain fatty acids. $4^{\text {th }}$ International Symposium on Energy from Biomass and Waste, San Servolo, Venice, Italy.

Hansson, A., Speda, J., Eliasson, M. and Karlsson, M. (2013) Addition of endogenous extra-cellular cellulolytic enzymes result in increased biogas production rate and yield from lignocellulosic material. Biomicroworld, Madrid, Spain. 2013. In: Industrial, Medical and Environmental Applications of Microorganisms. Current status and trends. Ed. Méndez-Vilas, A. Wagening Academic publishers, Netherlands. ISBN: 978-90-8686-243-6.

Hansson, A, Jonsson, B.-H. and Karlsson M. (2014). Activity and life time of commercial enzymes in excess sludge fluid and digester fluid. Abstracts of the “1 ${ }^{\text {st }}$ Green Gas Research Outlook Sweden”, Gävle, Sweden.

Odnell, A., Jonsson, B.-H. and Karlsson M. (2014). Activity, life time and effect of exogenous enzymes in biogas processes of waste water treatment plants. In: Conference Proceedings of the $7^{\text {th }}$ International Congress on Biocatalysis, Hamburg, Germany. 2014. ISBN: 978-3-941492-76-9. 


\section{Abbreviations and definitions}

Anaerobic digestion Microbial degradation of organic matter in absence of oxygen

BA Bicarbonate alkalinity

Biogas A gas produced by biological activity and composed of mainly methane and carbon dioxide

BMP Biochemical methane potential

Enzyme Biological protein catalyst

FOG Fat, oil and grease

HRT Hydraulic retention time, the average time a liquid spends in the reactor before being exchanged

Inoculum Microbial methanogenic community collected from a biogas reactor, and used to start a new biogas reactor

LCFA Long-chain fatty acids, fatty acids with 12 or more carbon atoms

OLR Organic loading rate. The amount of organic material (often expressed in VS) per reactor volume and day (g VS/L day)

TA Total alkalinity

TS Total solids

VFA Volatile fatty acids, fatty acids with less than 12 carbon atoms

VS Volatile solids

WAS Waste activated sludge

WWTP Waste water treatment plant 


\section{Contents}

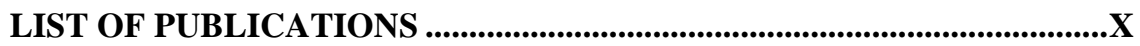

CONTRIBUTION REPORT ............................................................... XI

CONFERENCE CONTRIBUTIONS ...............................................................XII

ABBREVIATIONS AND DEFINITIONS ..................................................... XIII

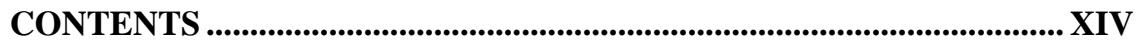

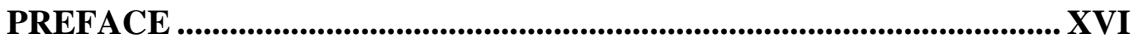

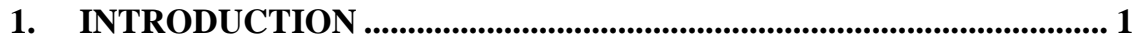

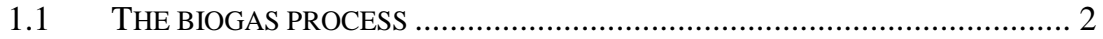

1.1.1 Microbiology of the biogas process ......................................... 2

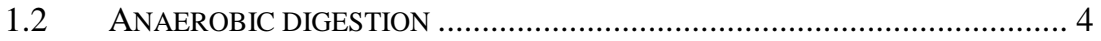

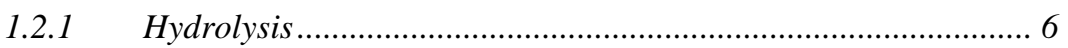

1.2.2 Acidogenesis ..................................................................... 6

1.2.3 Acetogenesis ......................................................................... 6

1.2.4 The methanogenesis ................................................................. 8

1.2.5 Syntrophic acetate oxidizer...................................................... 9

1.2.6 Homoacetogenesis ................................................................ 9

1.3 COMPONENTS FOR DEGRADATION IN THE BIOGAS PROCESS ..................10

1.3.1 Fat, oil and grease $(F O G)$.....................................................12

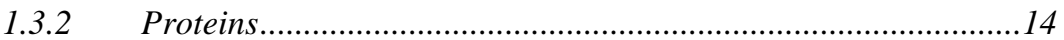

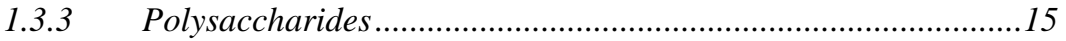

1.4 COMPOSITION AND LIMITATIONS OF PREVALENT BIOGAS SUBSTRATES 16

1.4.1 Slaughterhouse waste ................................................................16

1.4.2 Sludge from waste water treatment plants.................................18

1.4.3 Lignocellulosic biomass..........................................................19

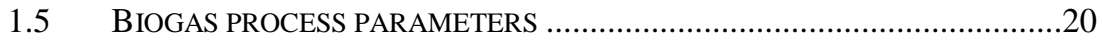

1.5.1 Total solids and volatile solids .................................................20

1.5.2 Substrate: Organic loading rate ..............................................2 21

1.5.3 Retention times........................................................................21

1.5.4 Substrate: degree of digestion ...............................................22 


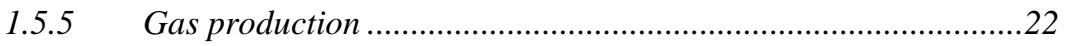

1.5.6 Gas composition ..................................................................23

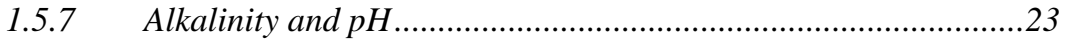

1.5.8 Volatile fatty acids and long-chain fatty acids.........................24

2. AIMS OF THE STUDY ….............................................................................25

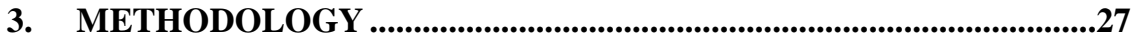

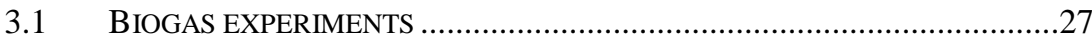

3.2 INDUCTION OF ENDOGENOUS CELLULASES ........................................30

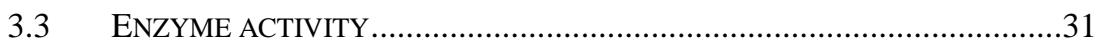

3.3.1 Fluorescence spectroscopy …….............................................

3.3.2 Absorption spectroscopy...........................................................

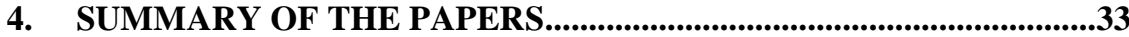

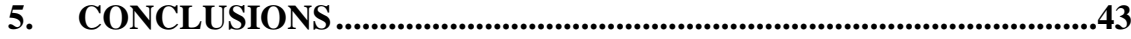

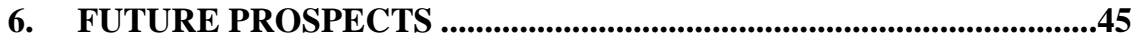

7. ACKNOWLEDGEMENTS ..........................................................47

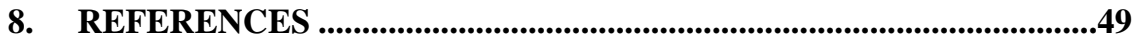




\section{Preface}

Today I realize that my interest for the biogas field started around 2008 when I had a summer job at a laboratory at a waste water treatment plant. It was the first time I came into contact with the biogas process. During my master thesis I focused on the biogas process and further on it lead me to this project. In this thesis, focus has been on how to influence the early stage of the anaerobic digestion process for increased biogas production from different substrates with early stage rate limiting steps.

The thesis summarizes the results from the studies that have been made. In the first chapter the reader will find an introduction to the scientific field, followed by a description of the used methods. A brief summary of the attached papers are thereafter described. Finally new thoughts and questions have been highlighted.

To meet the future environmental challenges more research is required within the field. Hopefully someone out there also will find it interesting and will continue the work?! Enjoy reading it!

Anna Odnell 


\section{Introduction}

Petroleum based fuel derived from crude oil is a finite and a non-renewable energy source and is the most used fuel globally. For a sustainable energy production it is therefore important to develop methods that make use of renewable energy sources. Another reason to change the energy source is because of the way that the use of fossil oil contributes to global warming. Fossil energy sources have been formed during millions of years and when combusting petroleum-based fuel as an energy source, the carbon dioxide emissions is an extra addition to the $\mathrm{CO}_{2}$ in the atmosphere. In many instances petroleum based energy could be replaced by biogas. Of course, the combustion of biogas also releases carbon dioxide to the atmosphere, however, that carbon dioxide is part of a natural continuous cycle and does not add net carbon dioxide to the atmosphere beyond what is already there (Deublein and Steinhauser, 2008).

Biogas can be used for heating by direct combustion or for production of electricity and heat by CHP (Combined Heat and Power) by combustion in biogas engines connected to generators. The biogas can also be used as a vehicle fuel, but need for this purpose to be upgraded to a methane concentration of approximately $97 \pm 2 \%$. Upgrading the biogas to vehicle fuel standard also requires removal of impurities such as hydrogen sulphide (Table 1) (Deublein and Steinhauser, 2008). 
Table 1- Impurities in the rawgas (Deublein, et al., 2008).

\begin{tabular}{ll}
\hline Component & Content (of volume) \\
\hline $\mathrm{H}_{2} \mathrm{~S}$ & $0-0.5 \%$ \\
$\mathrm{H}_{2} \mathrm{O}$ & $1-5 \%$ \\
$\mathrm{~N}_{2}$ & $0-5 \%$
\end{tabular}

Furthermore the by-product (digestate) can be used as a biofertilizer since it contains high amounts of nutrients such as phosphate and nitrogen (Energigas Sverige, 2018; Bryant 1979; Gerardi, 2003; Zinder, 1984).

To meet the demand for biogas and to make biogas production profitable it is important to increase both capacity and efficiency of existing plants.

\subsection{The biogas process}

Biogas is produced at anaerobic conditions by a battery of various microorganisms. The microorganisms degrade and metabolize organic matter such as proteins, carbohydrates and fats to finally methane, carbon dioxide and water. Compared to aerobic respiration less biomass is produced during anaerobic digestion. Biogas consists mainly of methane and a typical content of the produced gas in plants are methane (50-70 \%) and carbon dioxide (30-50\%), depending on the substrate mixture and process conditions (Benjaminsson, 2011; Energigas Sverige, 2018; Gerardi, 2003; Zinder, 1984; Deublein \& Steinhauser, 2008).

\subsubsection{Microbiology of the biogas process}

There are several types of microorganisms active during the anaerobic process, which all require organic matter (substrate) as energy source and nutrients for their survival. The substrate is in metabolic pathways degraded into smaller molecules (catabolism) which are subsequently used either as building blocks for the generation of new molecules from smaller units (anabolism) or for energy generation (Figure 1). Methane-forming bacteria have several enzyme systems which require trace elements, especially cobalt, iron, nickel and sulphur. Nutrients needed during anaerobic digestion can be hydrogen, carbon dioxide, and organic components such as polysaccharides, fatty acids and protein. The cells consist mainly of carbon (Table 2) (Gerardi, 2003; Schnürer, et al, 2009; Schnürer and Jarvis, 2009). 


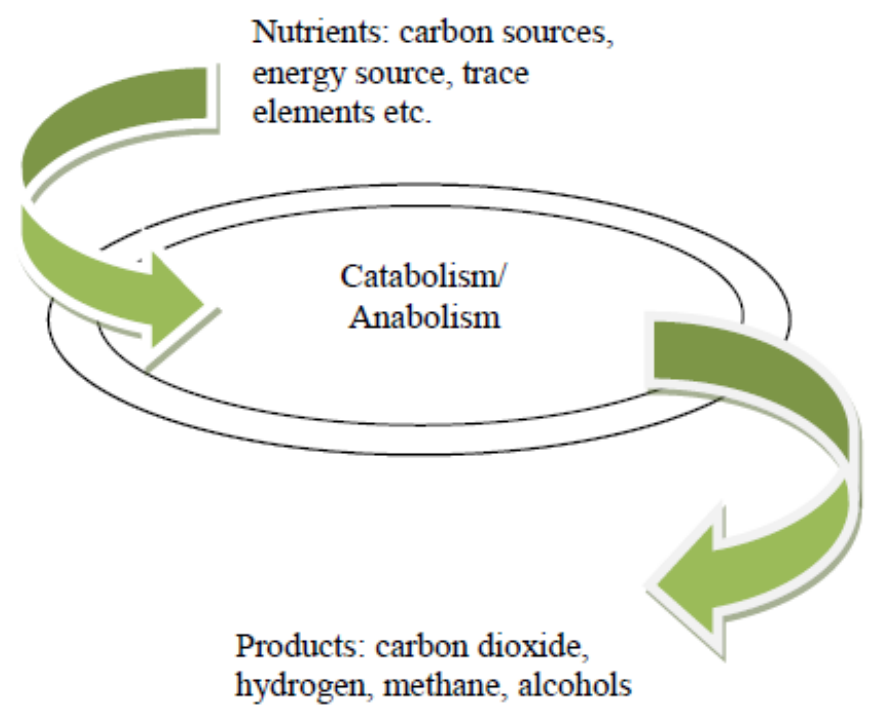

Figure 1- The metabolism of the cell, modified according to Schnürer and Jarvis.

Table 2- Element composition of bacterial cell (Schnürer and Jarvis, 2009).

\begin{tabular}{lcccccccccccc}
\hline Component & $\mathbf{C}$ & $\mathbf{O}$ & $\mathbf{N}$ & $\mathbf{H}$ & $\mathbf{P}$ & $\mathbf{S}$ & $\mathbf{K}$ & $\mathbf{N a}$ & $\mathbf{C a}$ & $\mathbf{M g}$ & $\mathbf{F e}$ & Other \\
\hline \% of dry weight & 50 & 20 & 14 & 8 & 3 & 1 & 1 & 1 & 0.5 & 0.5 & 0.5 & 0.5 \\
\hline
\end{tabular}

In contrast to aerobic respiration, that uses oxygen as an electron acceptor, anaerobic digestion which utilizes both fermentation and anaerobic respiration, requires electron acceptors other than oxygen in the anoxic process. The fermentation usually uses organic compounds as electron acceptors whereas the anaerobic respiration uses carbon dioxide, or inorganic electron acceptors such as manganese $\left(\mathrm{Mn}^{4+}\right)$, iron $\left(\mathrm{Fe}^{3+}\right)$, nitrite $\left(\mathrm{NO}_{3}{ }^{-}\right)$and sulphate $\left(\mathrm{SO}_{4}{ }^{2-}\right)$. The electron acceptors can be sorted due to how much energy that is produced, where oxygen releases most energy and carbon dioxide releases least energy (Schnürer and Jarvis, 2009).

$\mathrm{O}_{2}>\mathrm{Fe}^{3+}>\mathrm{Mn}^{4+}>\mathrm{NO}_{3}{ }^{-}>\mathrm{SO}_{4}{ }^{2-}>\mathrm{CO}_{2}$ Energy release 


\subsection{Anaerobic digestion}

In the anaerobic digestion process, an energy-rich end product will be obtained while less biomass is formed compared to aerobic digestion. Aerobic digestion oxidizes most of the substrate to water and carbon dioxide during production of biomass. The aerobic oxidation of glucose to carbon dioxide has a $\Delta \mathrm{G}^{0}$, of - $2840 \mathrm{~kJ}$ which can be compared to the $\Delta \mathrm{G}^{0}$, of the anaerobic oxidation of glucose to methane and carbon dioxide which is - $406.3 \mathrm{~kJ}$. That is, approx. 1/7 of that of aerobic oxidation (Bryant, 1979; Zinder, 1984).

The anaerobic digestion is a complex process and can be divided into the four different main stages of hydrolysis, acidogenesis, acetogenesis and methanogenesis (Figure 2). In each of these stages different microorganisms are active. The different microorganisms work in sequence in which one type of microorganisms products are the substrate of other downstream microorganisms, except of course for the final product methane, which is the most reduced form of carbon. Therefore, the microorganisms in the methanogenic microbial community need to be synchronized and in balance. If not, certain activities mid-process can become rate limiting and different inhibitory metabolic intermediates can accumulate as they are not consumed (Schnürer and Jarvis, 2009). 


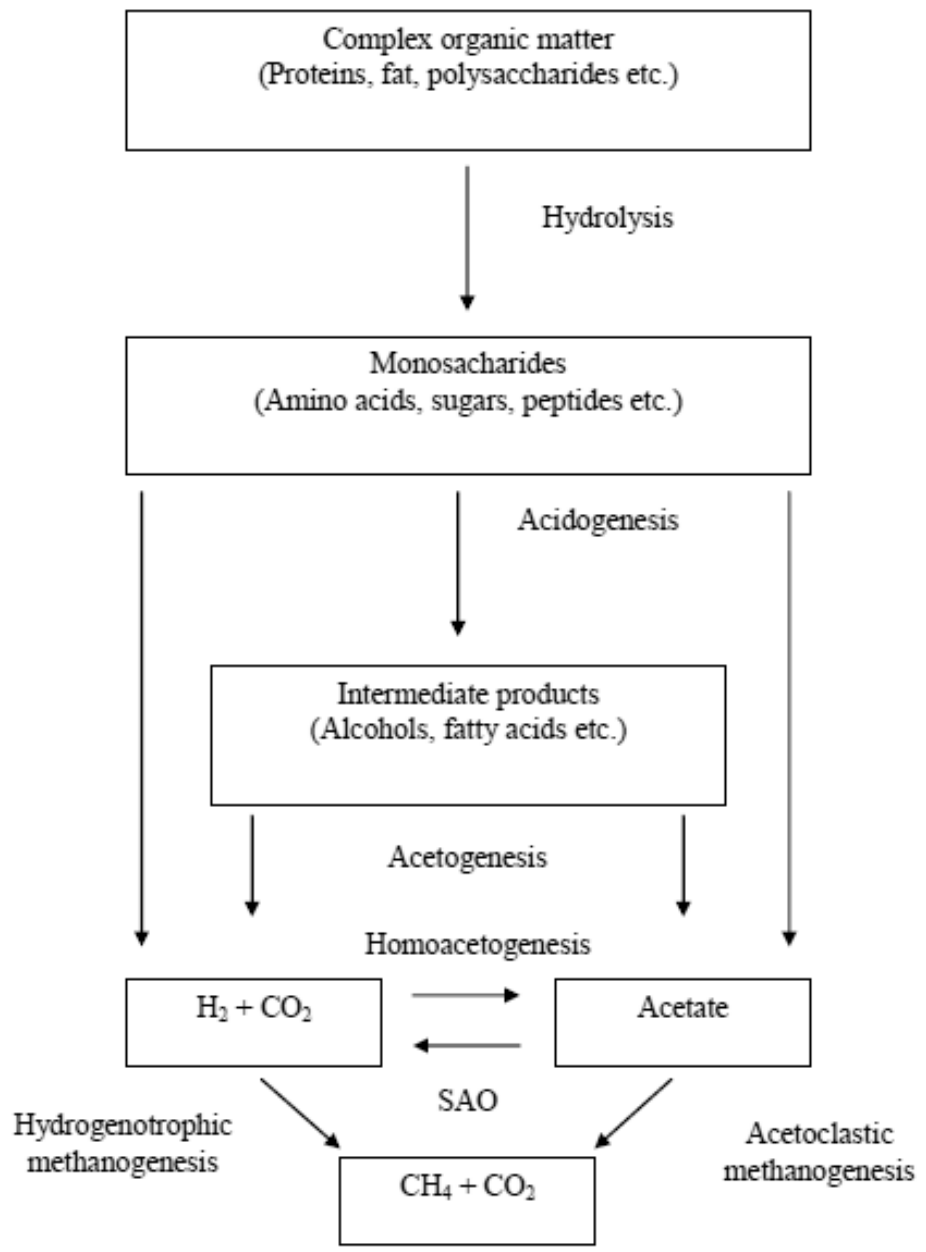

Figure 2- A schematic outline of the processes of anaerobic digestion 


\subsubsection{Hydrolysis}

In the first step, the hydrolysis, complex biopolymers such as proteins, polysaccharides and triglycerides are degraded to monomers such as amino acids, simple sugars such as glucose, and glycerol/long-chain fatty acids (LCFA). Extracellular hydrolytic enzymes excreted by the microorganisms in the anaerobic digestion are essential for degradation of the complex polymers. Amylases, cellulases, proteases, peptidases, lipases, phospholipases are all examples of hydrolytic enzymes secreted by different microorganisms. Certain structural components of substrates, like e.g. cellulose and keratin are often recalcitrant to hydrolysis, making the hydrolysis the rate limiting step of anaerobic digestion (Schnürer and Jarvis, 2009; Christy et al, 2014; Vavilin et al, 2008).

\subsubsection{Acidogenesis}

In the second step, the acidogenesis (or primary fermentation), the products from the hydrolysis are degraded to smaller compounds by different microorganisms which are both facultative and obligate anaerobic microorganisms. Amino acids can either be degraded separately, or in pairs by the Stickland reaction. When amino acids are degraded in pairs by the Stickland reaction, one amino acid works as an electron donor and the other one as an electron acceptor. During this step carbon dioxide, ammonia and acetate are produced (Madigan and Martinko, 2006; Deublein and Steinhauser, 2008).

Simple sugars are degraded to volatile fatty acids (VFA), carbon dioxide, hydrogen and alcohols. The products formed depend on the microorganisms; propionic acid is for instance produced by the propionic bacterium (Zinder, 1984; Deublein and Steinhauser, 2008).

\subsubsection{Acetogenesis}

The last step before methanogenesis is called acetogenesis (or secondary fermentation). In this step fatty acids longer than two carbon atoms and alcohols are degraded to acetate, carbon dioxide and hydrogen. The acetogenic microorganisms responsible for acetogenesis are also called hydrogen producers due to their production of hydrogen (Table 3). The hydrogen producing bacteria require a low hydrogen partial pressure, below $10^{-3}$ atmosphere, therefore they are obligatory coupled to hydrogen consuming bacteria such as hydrogenotrophic methanogens (Zinder, 1984; Deublein and Steinhauser, 2008). 
Table 3- Conversion of propionic acid and ethanol. Low hydrogen pressure makes both reactions favorable (Madigan and Martinko, 2006).

\begin{tabular}{lll}
\hline Reaction & $\boldsymbol{\Delta G}^{\mathbf{0}^{\mathbf{\prime}} \mathbf{a}}$ & $\boldsymbol{\Delta G}^{\mathbf{0}^{\mathbf{b}}}$ \\
\hline $\mathrm{C}_{2} \mathrm{H}_{5} \mathrm{COOH}+3 \mathrm{H}_{2} \mathrm{O} \rightarrow \mathrm{CH}_{3} \mathrm{COO}^{-}+\mathrm{HCO}_{3}^{-}+\mathrm{H}^{+}+3 \mathrm{H}_{2}$ & $76.1 \mathrm{~kJ}$ & $-5,4 \mathrm{~kJ}$ \\
$\mathrm{C}_{2} \mathrm{H}_{5} \mathrm{OH}+\mathrm{H}_{2} \mathrm{O} \rightarrow \mathrm{C}_{2} \mathrm{H}_{3} \mathrm{O}_{3}{ }^{-}+2 \mathrm{H}_{2}+\mathrm{H}^{+}$ & $9.68 \mathrm{~kJ}$ & $-36.08 \mathrm{~kJ}$ \\
\hline
\end{tabular}

${ }^{\mathrm{a}}$ hydrogen partial pressure $1 \mathrm{~atm}$, normal air pressure

${ }^{\mathrm{b}}$ hydrogen partial pressure $10^{-4} \mathrm{~atm}$

Since the methanogenic microorganisms require higher hydrogen partial pressure compared to acetogenic microorganisms they have to live in syntrophy with each other (literally meaning "eating together"). If the hydrogen is not consumed by hydrogentrophic methanogens the hydrogen partial pressure will increase and the acetogenesis will be inhibited with the following accumulation of propionate and butyrate (Gerardi, 2003; Deublein and Steinhauser, 2008).

The conversion of propionate to acetate and the conversion of hydrogen and carbon dioxide to methane has a small window of hydrogen partial pressure in which both are energetically favorable (Figure 3). A good indication of the productivity in the reactor is the concentration of propionate since this step it is often the rate limiting step during degradation of easily accessible substrates in the anaerobic process (Deublein and Steinhauser, 2008). 


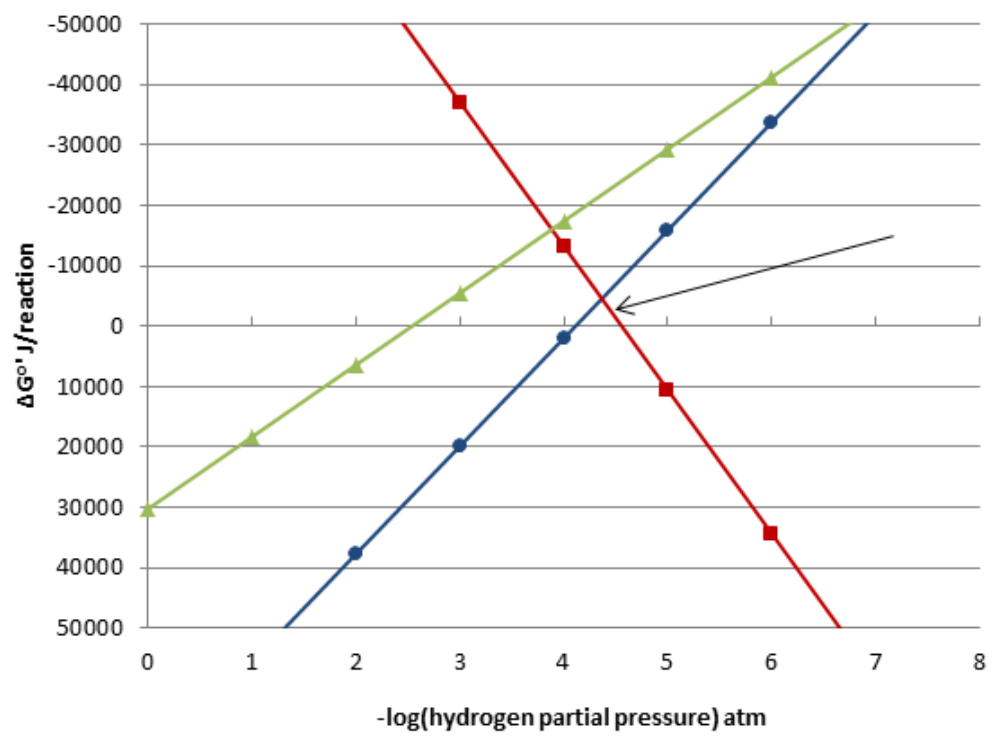

Figure 3- The figure shows the Gibbs free energy of the oxidation of propionate ( $)$ ) and butyrate $(\triangle)$, and of the methane formation $(\square)$ at different hydrogen partial pressures. The black arrow marks the small area where production of both methane and oxidation of propionate is favorable.

\subsubsection{The methanogenesis}

Unlike the microorganisms (bacteria) in the initial fermentation steps, the methane forming microorganisms belong to the phylogenetic domain archaea. Methanogenic archaea are strictly anaerobic and it is therefore important to avoid oxygen in the process. The methane forming bacteria can be divided into three different groups related to their substrate; hydrogenotrophic-, acetoclasticand methylotrophic methanogens. Earlier it was believed that in a "normal" process approximately $70 \%$ of the methane was produced from acetate and 27$30 \%$ was derived from carbon dioxide and hydrogen, whereas 0-3\% originated from methyl groups. However, more recent findings points to that hydrogenotrophic processes are equally important (Gerardi, 2003; Deublein and Steinhauser, 2008).

\subsubsection{Hydrogenotrophic methanogens}

These methanogens produce methane and water from carbon dioxide and hydrogen. Since these microorganisms use hydrogen as a substrate they help to maintain the low hydrogen partial pressure necessary for acetogenesis (Demirel and Scherer, 2008). There are further many hydrogenotrophic methanogens that 
can utilize formate as a source for electrons for reduction of carbon dioxide to methane (Khanal, 2008).

\subsubsection{Acetoclastic methanogens}

The acetoclastic methanogens convert acetate to methane and carbon dioxide (Demirel and Scherer, 2008). While the hydrogenotrophic methanogens prefer higher hydrogen partial pressure, acetoclastic methanogens prefer low hydrogen partial pressure, meaning that not only acetate formation will be favorable at low hydrogen partial pressures but also methane production by acetoclastic methanogens. A high partial pressure will decrease the fraction of methane produced from acetate (Gerardi, 2003).

\subsubsection{Methylotrophic methanogens}

Methylotrophic methanogens use methyl groups and produce methane from for example methanol and mono-, di- and trimethylamine. A methyl carrier helps the methyl group to be reduced to methane (Gerardi, 2003; Khanal, 2008).

\subsubsection{Syntrophic acetate oxidizer}

The acetoclastic methanogens can be inhibited by several substances such as ammonia, sodium, volatile fatty acids, heavy metals and sulphide. Schnürer et al 1999 described the anaerobic digestion during high concentrationa of ammonia. Ammonia inhibits acetoclastic methanogens, which is believed to be the most common route of methane production. However the study concluded that acetate was at high ammonia concentrations first converted to hydrogen and carbon dioxide. The conversion can proceed due to the activity of syntrophic acetate oxidizer (SAO) microorganisms. Besides the concentration of ammonia the concentration of acetate, and the activity of the methanogens affect by which route methane is produced. The hydraulic retention time (HRT) and the temperature have also been shown to affect the microbial community structure and thereby the formation of methane via the activity of SAO. How common this way of producing carbon dioxide and hydrogen is however not yet established. Low hydrogen partial pressure is required for formation of carbon dioxide and hydrogen from acetate (Schnürer and Jarvis, 2009).

\subsubsection{Homoacetogenesis}

Homoacetogenesis can be divided into two groups; heterotrophic acetogens and autotrophic acetogens. Autotrophic acetogens use hydrogen and carbon dioxide 
to produce acetate. The heterotrophic acetogens can utilize organic substrates such as formate and methanol. Since both methanogens and homoacetogens utilize hydrogen as an electron donor and that Gibb's free energy is similar there are possibilities that there is competition for the hydrogen (Khanal, 2008).

\subsection{Components for degradation in the biogas process}

Basically, all biogenic substrates are made up of the three classes of macronutrient biomolecules, namely, proteins, polysaccharides and lipids. These basic components give different amounts of total gas and different ratios of methane and carbon dioxide. The theoretical yield of each component can be calculated from the Buswell equation. Buswell created in 1952 an equation to estimate the products from the anaerobic breakdown of generic organic material of the chemical composition $\mathrm{C}_{\mathrm{c}} \mathrm{H}_{\mathrm{h}} \mathrm{O}_{\mathrm{o}} \mathrm{N}_{\mathrm{n}} \mathrm{S}_{\mathrm{s}}$ according to:

$$
\begin{gathered}
\mathrm{C}_{a} \mathrm{H}_{b} \mathrm{O}_{c} \mathrm{~N}_{d} S_{e}+\frac{1}{4}[4 a-b-2 c+3 d+2 e] \mathrm{H}_{2} \mathrm{O} \Rightarrow \\
\frac{1}{8}(4 a+b-2 c-3 d-2 e) \mathrm{CH}_{4}+\frac{1}{8}(4 a-b+2 c+3 d+2 e) \mathrm{CO}_{2}+d \mathrm{NH}_{3} \\
+e \mathrm{H}_{2} \mathrm{~S}
\end{gathered}
$$

When applied on substances that does not contain $\mathrm{N}$ or $\mathrm{S}$ these elements can be omitted. However, in the biogas produced from compounds also containing nitrogen, ammonia in the gas can be approximated to zero since almost all nitrogen will be dissolved as $\mathrm{NH}_{4}{ }^{+}$, whereas a large part of sulfur (although not all) will be dissolved and precipitated as metalsulfides. In fact, since also $\mathrm{CO}_{2}$ dissolve better than $\mathrm{CH}_{4}$ in water, the actually recovered gas will be slightly enriched for $\mathrm{CH}_{4}$.

When applied on for example a "standard protein" such as the 583 amino acids large bovine serum albumin (BSA) with a chemical formula of $\mathrm{C}_{2934} \mathrm{H}_{4615} \mathrm{O}_{897} \mathrm{~N}_{781} \mathrm{~S}_{39}$ it can be concluded that 1 mole of BSA (with the molecular weight of $66434 \mathrm{~g} / \mathrm{mole}$ ) will produce 1820 mole of $\mathrm{CH}_{4}$ and 1114 mole of $\mathrm{CO}_{2}$ (i.e. equating the original 2934 carbons). That is, the molar ratio will be $62 \% \mathrm{CH}_{4}$ and $38 \% \mathrm{CO}_{2}$, which will also be the composition of the biogas. From there it is further possible to calculate the volume of gas by applying the ideal gas law at standard conditions, giving that for example for 1 
$\mathrm{kg}$ of BSA (0,015 mole) 990 liter of biogas with a mixture of $62 \% \mathrm{CH}_{4}$ and $38 \%$ $\mathrm{CO}_{2}$ will theoretically be produced.

However, microorganisms do not "eat" proteins (or lipids or polysaccharides) but the hydrolysis products of these substrate components. That is, in order to be able to take up nutrients the microorganisms secrete hydrolytic and otherwise degrading enzymes for an extracellular digestion to provide smaller molecules. Therefore, the more correct calculation would be on the hydrolyzed state of proteins, polysaccharides and lipids. For the above example of BSA this mean that 582 water molecules need to be added to represent the protein as completely hydrolyzed into separate amino acids. Giving a chemical composition of $\mathrm{C}_{2934} \mathrm{H}_{5779} \mathrm{O}_{1479} \mathrm{~N}_{781} \mathrm{~S}_{39}$ for the set of amino acids produced from complete hydrolysis of BSA. This will give the exact same number of moles $\mathrm{CH}_{4}$ and $\mathrm{CO}_{2}$ (i.e. same volume) and of the same molar ratio per mole. However, per gram mass, the amino acids will give less gas because the molar mass of all amino acids of hydrolyzed BSA will be higher (with an additional $582 \mathrm{H}_{2} \mathrm{O}$ ). This is of little practical importance, unless it is the hydrolysis products that are used and weighed in as substrate, as in paper III.

Using the Buswell equation it is obvious that different substrate components are of different energetic value (Table 4), with a considerably higher potential for lipids, both in terms of total biogas production and in methane content. It could therefore be concluded that one should produce biogas mainly from lipids. However, to produce biogas from one or the other of the components is not possible because an appropriate ratio of carbon and nitrogen (and other elements) is needed for a viable microbial community, which is why codigestion can also be favorable to increase the methane yield (Carlsson and Uldal 2009, Schnürer and Jarvis 2009). In addition, even if certain components are of higher potential, the prevalence of polysaccharides, in the form of e.g. cellulose, hemi-cellulose and chitin, is much higher than proteins and lipids in nature.

Notably, the values in Table 4 are the highest theoretical values that can be obtained for each exemplified component. In reality this value is never reached since part of the nutrients are used for anabolism, i.e. the formation of new microbial biomass. Furthermore, it is assumed that all substrates are completely 
hydrolyzed within the residing time in an anaerobic digester. This is seldom the case since many substrates components are made up of structural components that are recalcitrant to hydrolysis (e.g. crystalline cellulose and proteinaceous collagen) or not completely accessible for hydrolysis as e.g. fats. Therefore, long hydraulic retention times are often needed to digest these types of substrate components and longer retention times will often result in higher methane yields, thus, different substrate components have different limitations.

Table 4- Biogas potential of different substrate components

\begin{tabular}{lllll}
\hline Component & Chemical formula & $\begin{array}{l}\text { Biogas } \\
(\mathbf{L} / \mathbf{k g})\end{array}$ & $\begin{array}{l}\mathbf{C H}_{\mathbf{4}} \\
(\boldsymbol{\%})\end{array}$ & $\begin{array}{l}\mathbf{C H}_{\mathbf{4}} \\
(\mathbf{L} / \mathbf{k g})\end{array}$ \\
\hline Cellulose & $\mathrm{nC}_{6} \mathrm{H}_{10} \mathrm{O}_{5}$ & 829 & 50 & 414 \\
Hemicellulose & $\mathrm{nC}_{5} \mathrm{H}_{8} \mathrm{O}_{4}$ & 848 & 50 & 424 \\
Generic Protein* & $\mathrm{C}_{1761} \mathrm{H}_{2771} \mathrm{O}_{539} \mathrm{~N}_{469} \mathrm{~S}_{23}$ & 990 & 62 & 614 \\
Triglyceride & $\mathrm{C}_{56} \mathrm{H}_{98} \mathrm{O}_{6}$ & 1416 & 71 & 1005 \\
tripalmitine) & & & & \\
Glycerol & $\mathrm{C}_{3} \mathrm{H}_{8} \mathrm{O}_{3}$ & 730 & 58 & 426 \\
LCFA (palmitic acid) & $\mathrm{C}_{16} \mathrm{H}_{32} \mathrm{O}_{2}$ & 1399 & 72 & 1005 \\
\hline
\end{tabular}

*There are a number of chemical formulas for "generic" proteins available in the literature that varies depending on biological source and thereby amino acid composition. However, the typical average length of a eukaryotic protein is approx. 400 amino acids and of prokaryotes approx. 300. In this case the generic chemical formula is that of BSA multiplied by 0.6 to get the generic formula of a protein of 350 aa with "BSA composition".

\subsubsection{Fat, oil and grease (FOG)}

Fats of triglycerides are the esters of three fatty acids chains and glycerol. The terms lipids, oils and fats are often used interchangeably. However, "lipid" is a general term and a lipid is not necessarily a triglyceride. Oil normally refers to a triacylglyceride lipid with short unsaturated fatty acids chains, which makes oils liquid at room temperatures, whereas triacylglyceride fats are normally solid at room temperature. Grease is a less well defined term and could refer to a number of substances such as used frying oil or waste vegetable oils and animal fats recovered from a grease trap. It still, however, largely refers to triacylglyceride lipids. The biological function of triacylglycerides are diverse, ranging from cell 
membranes to energy storage. The latter is important because as energy storage the natural function of the molecule is to be readily digested.

Triglycerides of fat, oil and grease (FOG) are rapidly converted to glycerol and long chain fatty acids (LCFA) in the anaerobic process (Hanaki and Nargase, 1981). Over $90 \%$ of the energy content (measured as chemical oxygen demand, COD) derives from the LCFA in the original FOG. Conversion of LCFA to acetate and formate/hydrogen use the $\beta$-oxidation pathway which involves proton-reducing acetogenic bacteria. Two families of synthropic Syntrophomonadaceae and Syntrophaceae converts LCFA to smaller molecules (Hatamoto et al, 2007; Jackson et al, 1999; Sousa et al, 2007; Wu et al, 2007). During anaerobic digestion of FOG, digestion of LCFA to methane is considered as the rate limiting step (Angelidaki and Ahring, 1992; Cirne et al, 2007; Hanaki and Nagase, 1981).

Degradation of FOG can cause process failure and co-digestion with sludge from WWTP have been shown to result in higher methane production (Davidsson et al, 2008; Girault et al, 2012; Luostarinen et al, 2009; Noutsopoulos et al, 2013; Wan et al, 2011; Wang et al, 2013). High concentration of LCFA can inhibit the anaerobic digestion of FOG. Two major ways of inhibition are described, adsorption of LCFA to the cell surfaces, which can cause toxicity and/or substrate transport limitations (Hanaki and Nagase, 1981; Rinzema, et al 1994; Pereira et al, 2005). The acetoclastic methanogens are believed to be the most sensitive to LCFA. However, the hydrogenotrophic methanogens and syntrophic bacteria have also been suggested to be sensitive to LCFA (Koster and Cramer, 1987; Lalman and Bagley, 2001; Rinzema et al, 1994; Hanaki and Nagase; 1981; Pereira et al, 2005; Roy et al, 1985; Lalman and Bagley, 2000; Lalman and Bagley, 2002).

An additional problem with FOG is that these components are lighter and not miscible with water. At high FOG load these components can therefore either coalesce to form larger drops in the reactor liquid, or even form a top layer in the biogas reactor which could lead to foaming. In both cases the hydrolysis of FOG will be impaired as hydrolytic lipases and phospholipases are only active in the liquid/FOG interface, and the larger the formed immiscible FOG droplets are, 
the less enzyme accessible liquid/FOG interface is displayed (Arpigny and Jaeger, 1999).

\subsubsection{Proteins}

Proteins are heteropolymers made up of the 20 different amino acids through peptide bonds. Proteins are degraded through hydrolysis by proteases and peptidases. However, and different from some types of triacylglycerides and polysaccharides, proteins have other functions than energy storage. Some are individual, motor proteins, receptors, signal transducers or enzymatic biocatalysts, whereas other, such as keratin and collagen are large polymeric structural proteins. Therefore, different proteins will be differently accessible to hydrolysis, although the basic composition of all proteins (the 20 amino acids) are the same. Once hydrolysed, amino acids can be metabolized via the Stickland reaction (Ramsay and Pullammanappallil, 2001).

Upon degradation in the anaerobic process ammonia is produced from the proteins. Ammonia $\left(\mathrm{NH}_{3}\right)$ and ammonium $\left(\mathrm{NH}_{4}{ }^{+}\right)$is in equilibrium in the environment, and the ratio depend on the temperature and $\mathrm{pH} . \mathrm{NH}_{3}$ can diffuse through the cell membrane and equilibrates the intracellular and extracellular concentrations. Two possible mechanism of inhibition caused by ammonia have been described; either $\mathrm{NH}_{3}$ inhibits the cytostolic enzymes, or the $\mathrm{NH}_{4}{ }^{+}$can be toxic through the effect on the $\mathrm{pH}$ in the cells or on the concentration $\mathrm{K}^{+}, \mathrm{Ca}^{2+}$ or $\mathrm{Mg}^{2+}$ ions (Sprott et al, 1984, Sprott and Patel, 1986).

The use of substrates with high amount of proteins is often not favorable, because inhibition by $\mathrm{NH}_{3}$ is common. The inhibiting concentrations of ammonia have been reported in several studies, although the result varies significantly (van Velsen, 1979; Angelidaki and Ahring, 1993). One reason for the diverse results reported for ammonia inhibition could be due to adaption of the micoorgansims for higher concentrations of $\mathrm{NH}_{3}$ (Chen et al, 2008). Studies have reported differences in ammonia inhibition between acclimatized and unacclimatized microbial communities by which inhibiting concentrations increased from 2.5 to $4.0 \mathrm{~g} / \mathrm{l} \mathrm{NH}_{3}$ and $\mathrm{NH}_{4}{ }^{+}$for un-acclimatized and acclimatized thermophilic methanogens, respectively (Hashimoto, 1986). Similar results have been observed where adapted process was tolerant to 3-4 g/ $\mathrm{NH}_{4}{ }^{+}-\mathrm{N}$ (Angelidaki and Ahring, 1993). 
The methanogens involved in the anaerobic digestion are the microorganisms that are the least tolerant to ammonia inhibitors (Kayhanian, 1994). Acetoclastic methanogens are more sensitive towards ammonia than hydrogenotrophic methanogens, and their activity decrease when the ammonia concentration increases. Thus, at high ammonia concentrations the acetate has to be converted to hydrogen and carbon dioxide through SAO before methanogenesis is performed by hydrogenotrophic methanogens and therefore the production route is shifted to SAO and hydrogenotrophic methanogenisis (Sprott et al., 1986; Salminen et al, 2002 a; Salminen et al, 2002 b; Westerholm et al, 2012).

In addition to the above, proteins are also a main source of sulfur originating from the amino acids cysteine and methionine.

\subsubsection{Polysaccharides}

Polysaccharides are a heterogenic group of molecules of long chains of polymeric carbohydrates composed of monosaccharides connected by glycosidic bonds. Depending on the constituting monosaccharides, the type of glycosidic linkage and the degree of branching, the polysaccharide will have different properties and functions. Some are highly branched and soluble, such as the glucose polymer dextran that forms the slime layer of bacteria. Other polysaccharides, such as the glucose polymers starch $(\alpha-1,4-$ glycosidic bond) and glycogen ( $\alpha-1,4-$ and $\alpha-1,6$ - bonds) functions as energy storage. As is the case for some oils, since the biological function of e.g. starch and glycogen is to serve as energy storage they are readily digested by hydrolytic enzymes (amylases) and metabolized and is not considered to be problematic in anaerobic digestion. However, the function of other major polysaccharides is structural, as is the case for e.g. cellulose ( $\beta-1,4$-gycosidic bond) and chitin. Thus, there function is to be physically and chemically stable and they are therefore recalcitrant to hydrolysis. Cellulose is recalcitrant to hydrolysis because the cellulose molecule is crystalline, making access to the polymer for hydrolytic enzymes restricted. Furthermore, in its natural form in plant cell walls the crystalline cellulose is intertwined with lignin and hemicellulose, making the cell wall even more chemically and physically stable (Cragg et al, 2015). 


\subsection{Composition and limitations of prevalent biogas substrates}

As mentioned in section 1.3, different components results in different amount of biogas and methane. Due to the composition of the various substrates, different substrates have different advantages and disadvantages in the biogas process.

\subsubsection{Slaughterhouse waste}

Slaughterhouse waste contains a high amount of protein and fat (Palatsi et al, 2011) and is therefore an attractive substrate for biogas production. However, treatment of slaughterhouse waste is therefore also attached with the problem associated with ammonia and LCFA. The problem with ammonia inhibition can in many cases be handled by mixing the slaughterhouse waste with substrates that are low in protein to reach a more beneficial $\mathrm{C} / \mathrm{N}$ ratio that allows much of the nitrogen to be incorporated in new biomass even at high protein degradation (Schnürer and Jarvis, 2009, Davidsson et al, 2008). Furthermore, much of the rate limitation of protein degradation is the actual hydrolysis rather than the ammonia inhibition from metabolism of amino acids. Slaughterhouse waste will for example contain large parts of cartilage which is the structural component of tendons, ear, nose, bronchial tubes, intervertebral discs etc. Cartilage is to a large part composed of collagen which makes up approximately $1 / 3$ of all proteins in animals. Collagen is formed as a triple helix of peptide chains to confer both flexibility and strength. In addition, collagen is more stable than other protein macromolecules because the amino acids lysine and proline are post-translationally modified to hydroxylysine and hydroxyproline to form more hydrogen bonds between the helix strands. Because of this architecture and structural function collagen is recalcitrant to hydrolysis.

For lipids on the other hand, much of the rate limitation is due to the immiscible nature of FOG. If lipids could be appropriately/fully mixed with the bioreactor liquid, the degradation of lipids would be faster since the enzymatic hydrolysis is fast if the lipids are appropriately mixed. Thus, any successful methods to mix lipids with the biogas reactor liquid will inherently produce more LCFAs faster, which will then become inhibiting. Thus, to utilize more lipids in a better way this inhibiting tendency of LCFAs need to be handled. 
In the anaerobic process, lipids are first hydrolyzed by extracellular enzymes, lipases, excreted by microorganisms to long chain fatty acids (LCFA) and glycerol (Figure 4). Thereafter LCFA and glycerol adsorbs to the cell surface and transported in to the cells for further degradation. The 3-carbon molecule of glycerol from hydrolysis of triacylglycerides poses no known problem in the process and is readily available for uptake and fermentation because if its high rate of permeability across membranes (Madigan and Martinko, 2006). The other hydrolysis product of triacylglycerides, the three LCFAs, are degraded by $\beta$-oxidation to acetic acid and hydrogen by syntrophic acetogenic bacteria (Weng and Jeris, 1976), and further degraded to methane by methanogenic Archaea (Sousa et al, 2009). As noted earlier, fat has a large biogas potential per kilogram.

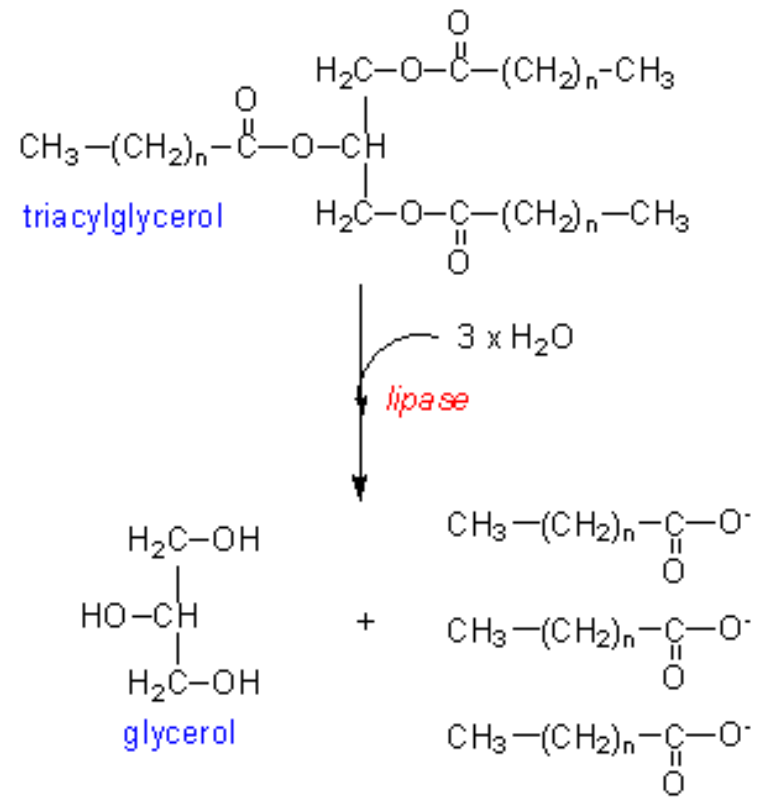

Figure 4- Hydrolysis of a triacylglycerol lipid

\subsubsection{Long chain fatty acids (LCFA)}

LCFA from hydrolysis of triacylglycerides are composed of a hydrophilic head (a carboxyl group) and a hydrophobic aliphatic tail. The tail can vary in length and degree of saturation; 12 or more carbons are defined as LCFA. Stearic acid, palmitic acid and oleic acid are all examples of LCFA (Table 5). Those and other LCFA are favorable for methane production if they are added in appropriate proportions. Over $90 \%$ of the methane potential from lipids comes 
from LCFA. According to Sousa et al 2009 there are 14 known syntrophic microorganisms that can degrade fatty acids with 12 carbon atoms or more. They belong to the families of Syntrophomonadaceae and Syntrophaceae. Of these, only three can degrade unsaturated long chain fatty acids (Battimelli et al, 2010; Cavaleiro et al, 2010; Koster et al, 1987; Sousa et al, 2009). Thus, with limited microbial diversity to handle LCFA, $\beta$-oxidation can easily become rate limiting at high FOG concentration and start to accumulate leading to inhibition of many processes (Angelidaki and Ahring, 1992; Cirne et al, 2007; Hanaki and Nagase, 1981).

Table 5- Various long chain fatty acids (LCFA).

\begin{tabular}{ll}
\hline LCFA & Molecular formula \\
\hline Stearic acid & $\mathrm{C}_{17} \mathrm{H}_{35} \mathrm{COOH}$ \\
Palmitic acid & $\mathrm{C}_{15} \mathrm{H}_{31} \mathrm{COOH}$ \\
Oleic acid & $\mathrm{C}_{17} \mathrm{H}_{33} \mathrm{COOH}$ \\
\hline
\end{tabular}

\subsubsection{Sludge from waste water treatment plants}

The annual production of sludge from waste water treatment plant (WWTP) in Europe is approximately 13 million metric tons of sludge dry matter (Eurostat, 2016). Assuming that the organic fraction of the dry matter (volatile solids (VS)) constitutes $65 \%$, and that the methane potential is $200 \mathrm{Nm}^{3} /$ ton VS and, further that the degree of degradation is $50 \%$, this would result in a methane production of 845 million $\mathrm{Nm}^{3}$ annually. This corresponds to 721000 tonne of oil equivalents (TOE). However, during 2013 only 125000 TOE was produced from urban and industrial waste water plants (EurObserv'ER, 2014). In Sweden there are 136 WWTP producing biomethane and the energy is $709 \mathrm{GWh}$, or approximately $35 \%$ of the annual energy production from all biogas plants in Sweden (Eriksson and Harrysson, 2017).

In Sweden there is just over 430 WWTP treating water from 2000 person equivalents (pe) or more and there is further approximately 1300 plants treating water for less than 2000 pe (Sundin et al, 2017). At conventional waste water treatment plants several different steps are normally included. The steps can be divided into three main steps; mechanical treatment, chemical treatment and biological treatment (Figure 5). There are primary three different sludges produced at WWTP; the primarily sludge from the pre-sedimentation step, waste 
activated sludge (WAS) from the biological step and sludge from the chemical treatment (Balmér, 2013).

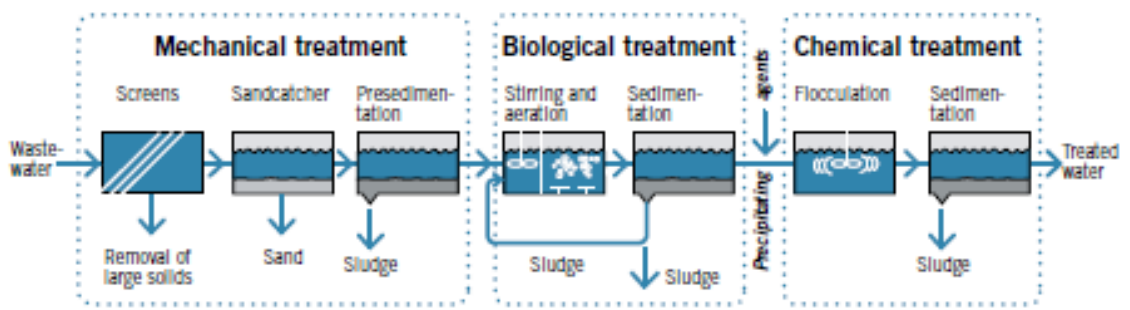

Figure 5- The three main steps at a conventional waste water treatment plant (Naturvårdsverket, 2014).

WAS is basically excess microbial biomass produced from consuming organic nutrients in the biological treatment step and is the sludge that is most recalcitrant to hydrolysis in the anaerobic processing of WWTP sludge (Gossett and Belser, 1982). Because of this recalcitrance the degree of digestion of WAS is often below $50 \%$ and many methods have been investigated to increase the hydrolysis and anaerobic digestion of WAS (Carrér et al, 2010). WAS consists of microbial biomass and extra polymeric substances (EPS) including polysaccharides, proteins, humic substances, uronic acids and deoxyribonucleic acids (Dey et al, 2006). The dominant part of WAS is proteins, constituting 40$60 \%$ of chemical oxygen demand (COD) (Tanaka et al, 1997; Donso-Bravo et al, 2011), followed by lipids and polysaccharides of approximately $25 \%$ and $15 \%$ COD, respectively (Wilson and Novak, 2009). Because of this composition also enzymatic pretreatments have been investigated, however, with varying success (Parmar et al, 2001, Parawira et al, 2012).

\subsubsection{Lignocellulosic biomass}

The annual natural production of lignocellulosic biomass is estimated to be in the order of 60 billion tons of organically carbon. The 6-carbon sugar glucose of cellulose can easily be converted to methane by anaerobic digestion or be fermented to ethanol by yeasts. Therefore, it is an important source for production renewable energy (Christopher et al, 2014). Lignocellulosic biomass for biogas production originates both from residuals biowaste such as house hold wastes and from cultivated bioenergy crops such as ley or whole plant cereals. Thus, energy production from lignocellulosic biomass is attractive also because it does not necessarily compete with food production. However, to 
make the monomeric glucose molecules available for microbial conversion it first need to be released from the lignocellulosic matrix and further hydrolyzed to the constituting glucose monomers, which is problematic because of the structural function of lignocellulose. Thus, lignocellulosic biomass is recalcitrant to hydrolysis and is therefore considered to be the rate limiting step in the anaerobic process of lignocellulosic biomass (Moiser et al, 2005, Hendriks et al, 2008).

The major component of plant cell walls is lignocellulosic biomass composed of cellulose, hemicellulose and lignin. Since the lignin is inert for biogas production and different plants have different proportions between the three major components, different types of plants have also different biochemical methane potential (Moiser et al, 2005, Hendriks et al, 2008). Much of the problem with lignocellulose is due to the structural integrity which makes the cellulose and hemicellulose inaccessible to hydrolytic enzymes. Therefore, large efforts have been directed to disintegrate the lignocellulose by various chemical, physical and thermal methods, such as steam explosion (Mussatto, 2016). However, these physical methods will only make the cellulose more readily accessible, but the cellulose still need to be hydrolyzed down to individual monomers of glucose. It was originally believed that this could be accomplished by the basic enzymes of endo-cellulases, exo-cellulases and $\beta$-glucosidases for cellulose hydrolysis. However, it has recently been found that for efficient hydrolysis of complex lignocellulose also other enzymatic activities are necessary (Müller et al, 2015; Kudanga and Le Roes-Hill, 2014; Pollegioni et al, 2015).

\subsection{Biogas process parameters}

In order to maintain process stability it is important to monitor different process parameters. Even a small change for example in temperature or $\mathrm{pH}$ can result in process instability and sometimes even in process failure. By controlling certain parameters the anaerobic process can be optimized and process instability be detected early.

\subsubsection{Total solids and volatile solids}

Total solids (TS) are the dry matter after heating to $105^{\circ} \mathrm{C}$ for at least 1 hour. It includes both organic and inorganic material. Volatile solids (VS) are the 
amount of the material that has vaporized at $550{ }^{\circ} \mathrm{C}$. VS is usually specified as percentage of TS.

$$
\begin{gathered}
\text { TS }(\%)=\frac{\text { Weight after heating to } 105^{\circ} \mathrm{C}}{\text { Weight before heating }} \times 100 \\
\text { VS }(\% \text { of TS })=\frac{\text { Weight after heating to } 105^{\circ} \mathrm{C}-\text { Weight after heating to } 550^{\circ} \mathrm{C}}{\text { Weight before heating }} \times 100
\end{gathered}
$$

It is important to take into account if there are high amounts of very volatile organic compounds such as VFA already in the original sample because it may give false (too low) results of VS in the sample since it can evaporate during the first heating step and, thus, result in a lower TS value than the real value (Svensk Standard SS 088113 edition 1; Pind, et al., 2003)

\subsubsection{Substrate: Organic loading rate}

The organic loading rate (OLR) is the amount of degradable substrates (VS) that is pumped into the digestion chamber every day (Schnürer et al, 2009).

$$
\mathrm{OLR}=\frac{\mathrm{kg} \mathrm{VS}}{\mathrm{m}^{3} \times \text { day }}
$$

\subsubsection{Retention times}

The retention time can be separated in hydraulic and solids retention times. The hydraulic retention time (HRT) is the average time an aqueous system is present in an anaerobic digester and is dependent of the volume liquid added and withdrawn from the reactor daily. That is, if in a reactor of $100 \mathrm{~m} 3$, ten cubic meters are added and withdrawn every day, the average HRT is 10 days. The solids retention time (SRT) is the average time solid matter is present in the reactor. The SRT can be increased from the HRT if the solid parts (mainly biomass) of the withdrawn volume is separated and returned to the reactor for prolonged treatment. However, for most reactors that are fully mixed and where no separation is used SRT is considered to be equal to HRT (Schnürer and Jarvis, 2009). 


\subsubsection{Substrate: degree of digestion}

The degree of degradation (DD) is a measure of the efficiency of the process, which can be determined through comparison of incoming and outgoing organic substances.

$$
\mathrm{DD}=\frac{\text { Organic substance }_{\text {in }}-\text { Organic substance }_{\text {out }}}{\text { Organic substance }_{\text {in }}}
$$

\subsubsection{Gas production}

Of the beneath described measures, it is the specific biogas production that is the most interesting because it tells something about how well the substrate is utilized. For example, if the organic loading rate is increased the specific gas production should remain the same if the process is unaffected by the increased load. If, however, the specific gas production decreases, this is an indication that the substrate is not degraded to the same extent as before. The specific gas production can also be used to understand if e.g. a substrate pretreatment method has a positive effect on the substrate degree of degradation. That is, for a pretreatment method that lead to higher release of organic material and increased degree of digestion, this would result in an increased specific gas production (i.e. more gas per mass substrate) as compared to an untreated substrate at the same organic loading rate.

$$
\begin{gathered}
\text { Total gas production: } \mathrm{m}^{3} \times \text { day } \\
\text { Volumetric gas production }=\frac{\mathrm{m}^{3}}{\mathrm{~m}^{3}{ }_{\mathrm{RV}} \times \text { day }}
\end{gathered}
$$

The volumetric gas production relates to the biogas produced to the biogas reactor volume.

$$
\text { Specific gas production }=\frac{\mathrm{m}^{3}}{\mathrm{~kg} \mathrm{VS} \times \text { day }}
$$

The specific gas production relates to the substrate composition and the degree of degradation. 


\subsubsection{Gas composition}

Furthermore, if the composition of the substrate is known it can be understood which part of the substrate is best degraded. For example, if a hypothetical substrate were composed of $50 / 50$ protein and cellulose the methane concentration should be approx. 58\% because of the higher gas production and higher biomethane potential of proteins (Table 4). A significantly lower number would indicate that the proteins $\left(62 \% \mathrm{CH}_{4}\right)$ are not degraded to the same extent as the cellulose $\left(50 \% \mathrm{CH}_{4}\right)$, and vice versa. Thus, just as the specific gas production gives information about the biogas process, so can the $\mathrm{CO}_{2} / \mathrm{CH}_{4}$ composition.

It is also of interest to investigate the amount of hydrogen sulphide $\left(\mathrm{H}_{2} \mathrm{~S}\right)$ in the gas. A high proportion of hydrogen sulphide in the gas can be indications of a substrate with high concentrations of certain amino acids (e.g. BSA, Table 4), sulphate or sulphide (Schnürer, et al., 2009).

\subsubsection{Alkalinity and pH}

Alkalinity is a way of estimating the buffer capacity in a liquid. A high alkalinity gives a good buffer capacity and thereby a stable $\mathrm{pH}$. Alkalinity can be measured as total alkalinity (TA) and bicarbonate alkalinity (BA). TA includes bicarbonate, ammonia and VFA. BA includes bicarbonate and ammonia. Bicarbonate has a $\mathrm{pKa}_{1}$ of 6.35 and a $\mathrm{pKa}_{2}$ of 10.33 . Ammonia has a pKa of 9.25 and VFA has $\mathrm{pK}_{\mathrm{a}}$ lower than $\mathrm{pH}$ 5. BA is the most common way of monitoring the alkalinity since it excludes VFA. Exclusion of VFA is made by titrating only to a higher $\mathrm{pH}$ (5.4) than their $\mathrm{pK}_{\mathrm{a}}$. A stable process usually has a BA between $3000-15000 \mathrm{mg} \mathrm{HCO}_{3}^{-} / 1$. High amounts of VFA result in a high TA, and accumulation of VFA is an indication of an instable process and not a good sign. A strong acidification is avoided with the carbon dioxide/ hydrogen bicarbonate/ carbonate buffer system which is most effective around $\mathrm{pH}$ 6.5. A weak acidification is avoided by the ammonia/ ammonium buffer system which is most effective around pH 10 (Pind, et al., 2003).

The $\mathrm{pH}$ is a measure of the proton activity, which reflects all cations and anions in the solution. $\mathrm{pH}$ can thereby indicate changes in the chemical balance, such as acids, bases, anions and cations produced or consumed during metabolic activity. Since ammonia, VFA and carbonate can stabilize the $\mathrm{pH}$ or at least 
affect the $\mathrm{pH}$ it can be difficult to interpret the $\mathrm{pH}$ results. Due to this $\mathrm{pH}$ is only used together with other parameter (Pind, et al., 2003). The methanogenic microorganisms are sensitive to changes in the $\mathrm{pH}$ value. Their optimum $\mathrm{pH}$ is between 6.5 and 7.2. The acidogeneic microorganisms are more $\mathrm{pH}$ tolerant compared to methanogens, as they can function in the $\mathrm{pH}$ range between 4.0 and 8.5. It is important to optimize the $\mathrm{pH}$ for methanogenic microorganism since they often constitute the bottleneck in the anaerobic process. The VFA produced during the anaerobic digestion reduces the $\mathrm{pH}$. This is counteracted by the methanogens which consume acetate and produce carbon dioxide, a part of the alkalinity (Deublein, et al., 2008; Khanal, 2008; Pind, et al., 2003; Schnürer, et al., 2009).

\subsubsection{Volatile fatty acids and long-chain fatty acids}

During hydrolysis, acidogenesis and acetogenesis different types of fatty acids are produced. Finally these acids are converted to carbon dioxide and methane. Accumulation of volatile fatty acids (VFA) will be an effect for example if the methanogens are inhibited. Overloading can also be a reason of accumulation of fatty acids and is due to that the hydrolytic and acidogenic microorganisms grow faster than the methanogens. The conversion of acetate to methane and carbon dioxide will then become the rate limiting step. Accumulation of fatty acids leads to a decreased BA and thereby a decreased $\mathrm{pH}$. The fatty acid concentration is therefore a good indication of the stability of the process. Fatty acids can be divided into volatile fatty acids (VFA) and long-chain fatty acids (LCFA). Thus VFA is a product from LCFA and analysis of LCFA can thus indicate process instability in earlier stages such as the acidogenesis. Both VFA and LCFA can be analyzed by gas chromatography (GC) and high-performance liquid chromatography (HPLC) (Jonsson, et al., 2002; Schnürer, et al., 2009). 


\section{Aims of the study}

Finding improvements in the anaerobic digestion process are interesting for increased biogas production and for biogas to be an even better alternative to fossil fuels for heat-, electricity or vehicle fuel production. The main focus of the work has been to find improvements in the initial rate limiting steps in the anaerobic digestion of different substrates; slaughterhouse waste, sludge from municipal waste water treatments plants (WWTP) and lignocellulosic material. Several investigations were undertaken in order to:

Identify the cause, and relief, of inhibition that had earlier been noted in batch experiments of slaughterhouse waste in presence of zeolites (paper I).

Investigate the enzymatic activity life time of hydrolytic enzymes in different sludge environments at WWTP. And, furthermore, to understand the cause of inactivation and to evaluate the possibilities to use hydrolytic enzymes to improve the biogas production from WWTP sludge (paper II).

Examine the effect of adding a mixture of cellulolytic enzymes, that were naturally produced by a methanogenic microbial community, to a biogas process treating lignocellulosic substrate (paper III). 


\section{Methodology}

\subsection{Biogas experiments}

Biogas experiments can be carried out both as continuous processes and in batch experiments. In continuous experiments bench top laboratory bioreactors are used whereby substrate is continuously added and residual digestate is continuously withdrawn, thus, mimicking full-scale processes. These types of experiments are valuable because they give information about long-term effects such as microbial adaptation to new substrates/conditions, and whether certain metabolites are slowly accumulating. However, they are also cumbersome and slow, because to find these effects, long experiments that are hard to start over or reproduce is necessary.

An alternative to continuous processes is to use batch experiments, in which a bacterial inoculum from a continuous reactor is mixed with a known amount of substrate (and possibly an anaerobe medium) in a sealed bottle. Thus, in this case nothing is added or withdrawn after the experiment has commenced. This type of experiment is therefore not suitable for studying long term effects. In addition, it is easy to over-interpret results in terms of kinetics of biogas production as the results are not necessarily comparable with continuous experiments because many factors can influence the results. For example, if a too low number of viable microorganisms are added there may be a lag phase because an initial bacterial growth is first necessary. Also, since it is a closed system, any inhibiting metabolites produced will not be washed out and will remain and possibly accumulate in the system. Thus, absolute values from batch experiments should be treated with great care. 
Nevertheless, batch experiments are used for determining the "biochemical methane potential" (BMP) of various substrates. In principle a batch experiment can go on "forever" to find the maximal biogas yield that can be had from a substrate. However, in practice BMP tests are terminated when biogas production has ceased and reached a plateau. In addition, batch experiments can be suitable to monitor the relative effects of e.g. substrate pretreatments on biogas production kinetics (Figure 6.A) against an untreated reference, or for finding effects on BMP from a certain pretreatment (Figure 6.B). That is, to find if more microbially accessible substrate is released from the pretreatment.

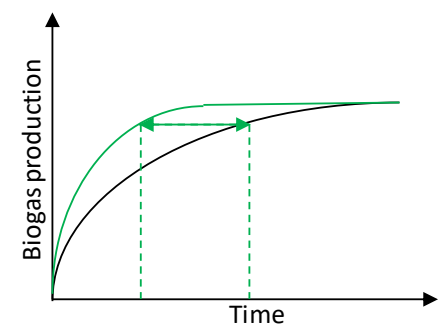

\section{A}

Increase of biogas production rate

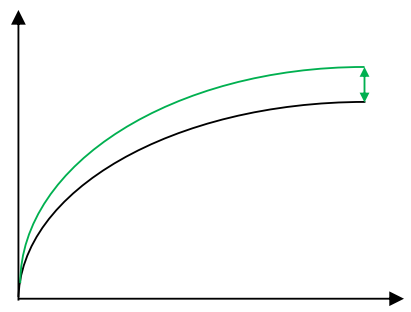

B

Increase of biogas production degree of degradation

(increased BMP)

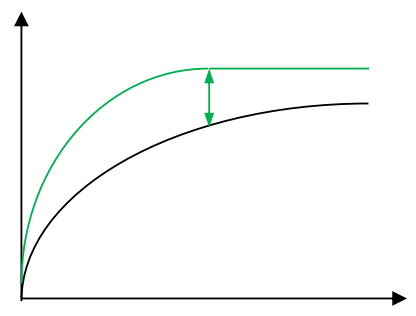

$\mathrm{C}$

Combination of both

Figure 6- Batch experiments for monitoring BMP were carried out in paper I and paper III. Figure A Increased biogas production rate compared to reference, $\mathrm{B}$ increase of biogas production degree of degradation and $\mathrm{C}$ a combination of $\mathrm{A}$ and $\mathrm{B}$. 
Different inoculums were used in the experiments depending on the investigated substrate. The ratio between inoculum and substrate was $2: 1$ based on volatile solids (VS). Trace elements were used in both studies, for recipe see paper I and paper III. All experiments were made in triplicates. The gas pressure and methane concentration was measured and used for calculating the biomethane production. When the gas production ceased the experiments were determined and the biochemical methane potential could be calculated.

Batch experiments were also conducted in paper II. However, in this case it was not the BMP that was of interest but rather the momentarily effect of various enzymes. The only effect an enzyme has is to catalyze and speed up the rate of reactions without itself being consumed in the process. Thus, in principle, the addition of small amounts of enzymes should not influence the level of BMP, only the time to reach BMP (Figure 6.A). However, BMP could of course be influenced if the higher rate of hydrolysis of a certain substrate component leads to the release of another inaccessible substrate component.

Therefore, in paper II the batch experiments were initiated and at certain time points enzymes were added. Thus, in this case the batch experiments were rather fed-batches, since substances were added to the batch bottles after the experiment had commenced. By continuously monitoring the biogas production rate the effect of various enzymes could be determined. Since this effect is not eternal (effect will cease either when all enzyme specific substrate is hydrolyzed, or when the enzyme is inactivated) the information asked for was received almost immediately upon enzyme addition (Figure 7). 


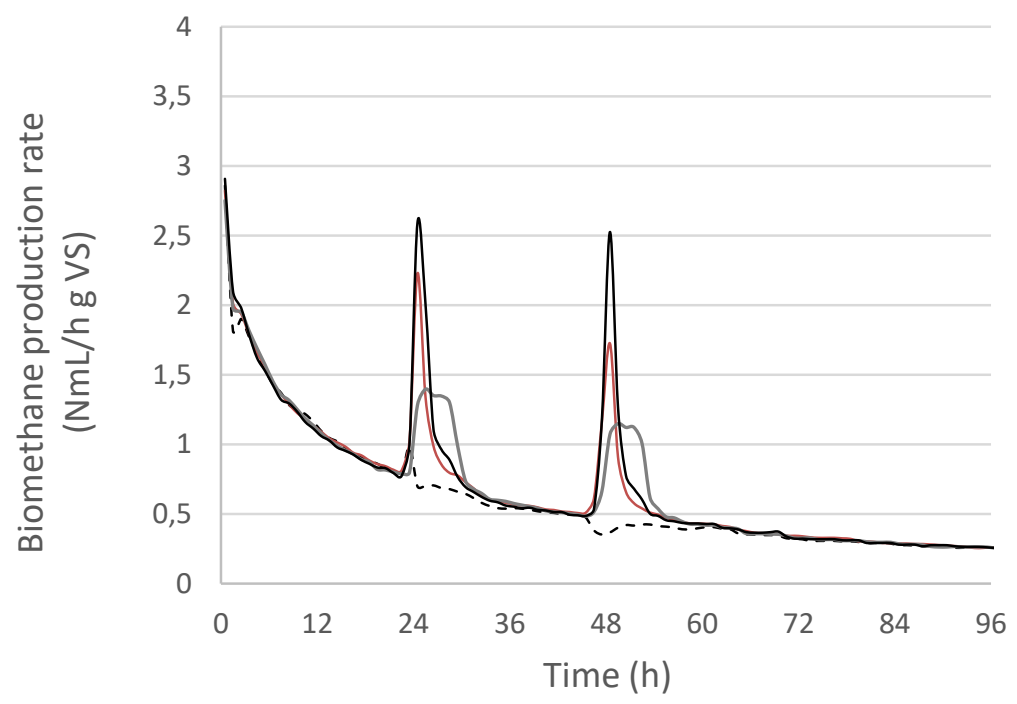

Figure 7- Results for enzyme batch experiments. Biomethane production rate upon addition of cellulase (-), $\alpha$-amylase $(-)$, BSA (positive control) (-) and reference with no enzyme/protein added (- - -) (paper II).

\subsection{Induction of endogenous cellulases}

In paper III evolutionarily adapted cellulases endogenous to a methanogenic microbial community were induced and collected. The source of cellulolytic enzymes derived from a microbial community maintained at metabolic steady state on a chemically defined medium in a controlled constructed environment (Speda, et al, 2016). For the microorganisms to start and overexpress cellulose degrading enzymes the "evolutionarily-economic principle of microbial metabolism" was used (Allison et al, 2011). This principle states that enzyme production should increase when simple nutrients are scarce and complex nutrients are abundant. Since also the reverse should be true, the microbial community was first maintained on a chemically defined medium of monomeric nutrients i.e. glucose, amino acids and fatty acids. That is in a condition where simple nutrients were abundant to suppress enzyme production. Production of cellulolytic enzymes were then "kick-started" by transferring cells to a batch bottle with the glucose exchanged for cellulose, by which the microbial community is forced to produce cellulolytic enzymes to make available glucose. This enzyme mixture of high, biogas community specific, cellulolytic activity was then tested for effect on anaerobic digestion of a lignocellulose substrate. 


\subsection{Enzyme activity}

Enzymes catalyze a certain reaction or general conversion of a substrate to a product, more rapidly than would be the rate for the uncatalyzed reaction. Several different methods can be used for detection of enzymatic activity. In this study two similar approaches have been used fluorescence spectroscopy and absorption spectroscopy (Bisswanger, 2013).

\subsubsection{Fluorescence spectroscopy}

Fluorescence spectroscopy can be used for detection of enzyme activity. Usually a substrate is bound to a fluorophore and upon of enzyme activity the fluorophore is released and can thereby be detected with fluorescence (Bisswanger, 2013; Lakowicz, 2006; Nybroe et al, 1992).

Fluorescence is a process in which an electron is excited from its ground state to a higher energy level. The electron releases the energy by emitting light and returns to the ground state. The emission of light can be measured and thereby information can be received on whether the enzyme is active or not (Lakowicz, 2006).

\subsubsection{Absorption spectroscopy}

The method is simple to use. A light source is used and the light penetrates the solution. If the solution absorbs light of a certain wavelength the light will not be transmitted through the solution. Thus, there will be a difference in light absorbing substance and a reference not containing the substance, and the spectrophotometer will display the measured absorbance value (Bisswanger, 2013).

Similar substrates are used as for fluorescence spectroscopy where a substrate for the enzyme is linked to a fluorophore (dye). Upon enzyme activity the fluorophore is released and the absorbance can be measured at a certain wavelength (Nybroe et al, 1992). 


\section{Summary of the papers}

\section{Paper I: Zeolites relieves inhibitory stress from high concentrations of long chain fatty acids}

In an earlier work (Nordell et al, 2009) it was found that methanogenesis in BMP tests of slaughterhouse waste was inhibited resulting in a long lag phase before biogas production commenced. It was also noted that this inhibition could be relieved by the addition of zeolites, thus, zeolites could possibly be used for more efficient biogas production from slaughterhouse waste. Zeolites are micropourous aluminosilicate minerals and are commonly used as adsorbents. Question was then how zeolites acted and on what component.

In paper I the effect upon addition of zeolites to anaerobic digestion of slaughterhouse waste was therefore further investigated. Slaughterhouse waste contain high amounts of fat which is attractive as substrate since the biomethane potential is high. During anaerobic digestion fat is first hydrolyzed to long chain fatty acids (LCFA) and glycerol. LCFA and glycerol are transported in to the cells and further digested to finally methane and carbon dioxide. Nevertheless, the LCFA consuming microorganisms can be rate limiting due to their slow growth and their requirements for a low hydrogen partial pressure. Thus, an early, fast production of LCFA can result in high concentrations of undigested and accumulating LCFA, which can then lead to process inhibition.

To establish that the inhibiting component was in fact a metabolite, zeolites were used to treat both the incoming substrate and the anaerobic digestion process. Since zeolites did not relieve the inhibitory effect when only the substrate was treated with zeolites before anaerobic digestion it could be 
concluded that the inhibitory substance was not a part of the incoming slaughterhouse substrate but was produced in the anaerobic digestion.

Upon spiking the process with pure LCFA (stearic and palmitic acid) the lag phase was strongly prolonged. However, when mixed with zeolites the lag phase returned almost completely to the same as for slaughterhouse waste only (Figure 8). Thus, the added zeolites acted on LCFA. It was further found that when zeolites were not added, the slow biomethane production led to an accumulation of acetic acid. Thus, verifying that the free LCFA appeared to mainly inhibit acetic acid consumers, like e.g. acetogenic methanogens (see 1.3.1). Consequently, when zeolites were added to the LCFA spiked samples, the inhibitory effect of LCFA was relieved and acetic acid could be consumed by biomethane production and the concentration of dissolved acetic acid decreased.

Thus, the work showed that zeolites can be used to incapacitate the inhibitory effect of LCFA produced in the anaerobic digestion of fat rich substrates such a slaughterhouse waste.

Another interesting result that was not much discussed in the paper was the finding that the presence of zeolites regularly provided more consistent results between replicates (see error bars Figure 8). Thus, it is possible that the addition of small amounts of zeolites could provide more reliable results of any BMP test. However, this would need to be tested on several substrates. 


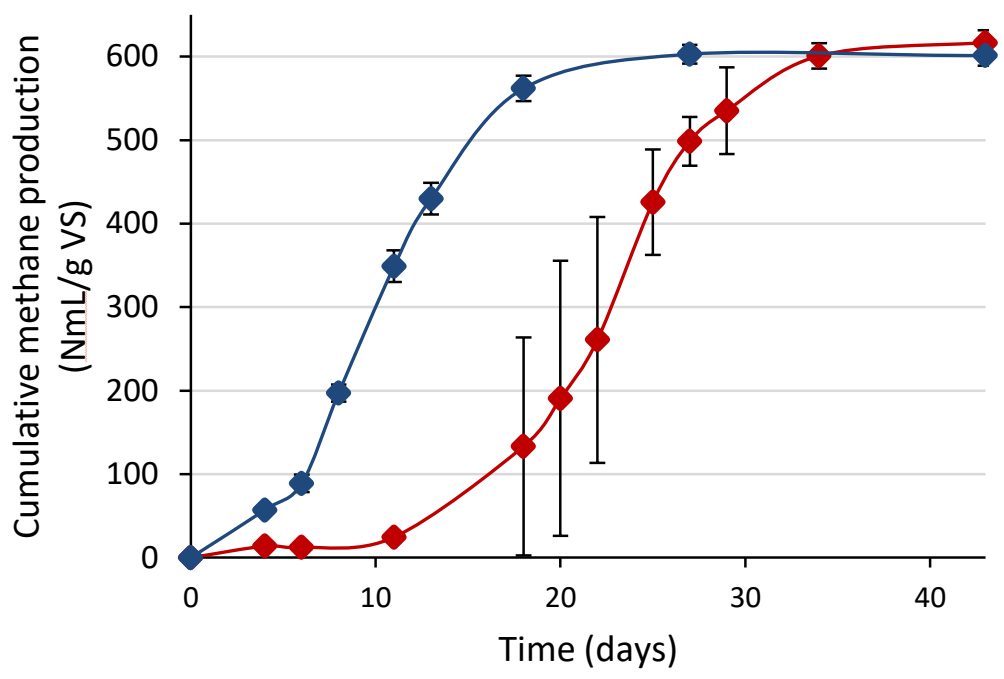

Figure 8- BMP test of slaughterhouse waste. Spiked with LCFA (-) and spiked with LCFA + addition of zeolites (-).

\section{Paper II: Activity, life time and effect of hydrolytic enzymes for enhanced biogas production from sludge anaerobic digestion}

The degree of digestion of WWTP sludges are often low $(\leq 50 \%)$ and in particular WAS has been found to be recalcitrant to anaerobic digestion. The low degradation also depends on the short hydraulic retention time (HRT) at WWTP. To increase the degree of degradation, within the HRT, the hydrolysis of the substrate therefore need to be improved.

Compared to many very energy intense physicochemical methods for pretreatment of sludges, enzymes are an attractive candidate for energy efficient improved hydrolysis. This has been investigated in many previous projects, however, with very varied results. In addition, in many projects technical grade liquid enzyme preparations have been used. Thus, enzymes mixed with many other organic substances (residual growth medium, enzyme stabilizing glycerol etc.) have been used. In addition, in many cases mixtures of enzymes have been used, meaning that when an effect has been noted it has not been possible to establish which of the enzyme activities that had an effect. Largely, many previous work has been trial-and-error attempts by adding enzymes and see what happens. That is, what does the enzyme addition do to the anaerobic digestion? 
Using enzymes are, however, only feasible if the enzymes have a high activity and long enough life time in the selected environment. Therefore, in paper II we were equally interested in the reverse. That is, what does the anaerobic digestion do to the enzymes? For this reason, highly pure enzymes were individually tested for activity life time in both substrate (WAS) and anaerobic digester (AD) environment. Equally important is it to understand which enzymes that has a natural substrate in the substrate. WAS consists of microbial biomass and extracellular substances (EPS), comprising polysaccharides, proteins, humic substances, uronic substances and deoxyribonucleic acids. According to this, and earlier performed studies, several enzymes were selected; proteases, cellulases, $\alpha$-amylase and lysozyme.

Although the life time of the enzymes in the environments differed slightly, the enzymes were always inactivated within $24 \mathrm{~h}$. In one case the enzyme where not at all active (cellulase in $\mathrm{AD}$ liquid), probably because there were some substance(s) in the liquid which inhibited the catalytic function. In all other cases the enzyme was initially active, but for an unknown reason the activity decreased rapidly over time. However, when protease inhibitors were added, the activity life time were in most cases increased, indicating that the inactivation mechanisms were due to endogenous protease activity in the respective environment. This was further verified by the prolonged activity life time of modified (serin protease protected) trypsin and observed fragmentation of cellulase after incubation in the two environments.

This was not an unexpected result since enzyme addition to both WAS and anaerobic digester liquid means that the enzymes are added to environments of very high microbial activity, whose purpose is to digest biomolecular substances, of which enzymes are one. Thus, what anaerobic digestion does to the enzymes is to proteolytically digest them.

Despite these results the enzymes were tested for effect on biogas production rate to investigate how much organic material they could release within their activity life time. To take into account the added organic load an enzymatically inactive protein (bovine serum albumin) was added to the same amount as the tested enzymes and used as a control. 
As expected, addition of the inactive cellulase did not provide any net effect on biogas production rate or yield. Neither did $\alpha$-amylase, either because the enzyme where not active or, just as likely, because there is not much residual undigested starch present in the anaerobic digester. The cell wall degrading enzyme lysozyme displayed a small, slow net effect on biomethane production. However, addition of proteases provided a much faster and larger net effect, and in particular so for the protease subtilisin. In fact, addition of subtilisin resulted in three times as fast biomethane production rate at its peak value (Figure 9 A), leading to a significantly increased net accumulated biomethane production (Figure 9 B) of approx. $37 \%$ at 24 hours after enzyme addition. This meant two things. First, the enzyme was active also in the complete anaerobic digester environment, and second, that there was residual protein to act on.

However, the biomethane production rate ceased quite fast after enzyme addition and the rate returned to the same as for the untreated reference within approx. $12 \mathrm{~h}$. Thus, this could be an effect of either the protease being inactivated, or that all protein had been degraded and consumed. However, upon a second addition of subtilisin the biogas production rate again increased, indicating that there were still undigested protein present and that the first decrease of biogas production rate was in fact caused by inactivation of the enzymes, in accordance with the activity life time studies. 


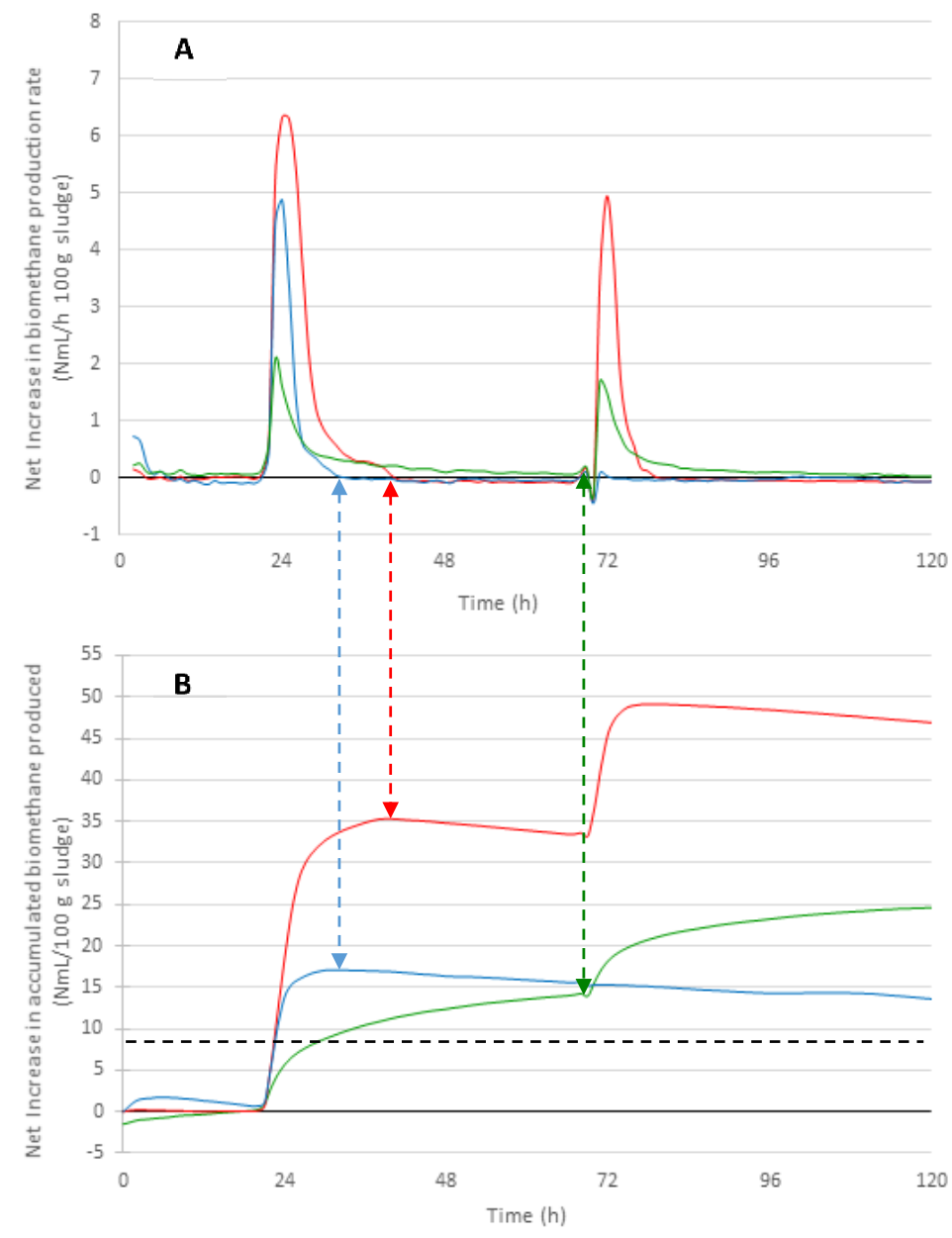

Figure 9-A. Net increase in biogas production rate and B. net accumulated biogas produced upon first and second addition of subtilisin (-) and lysozyme (-) and the single addition of trypsin (-), relative to the reference. That is, in panel $\mathrm{A}$, at a $\mathrm{y}$-axis value of zero there is no difference in gas production rate between the experimental batch bottle and the reference. The broken horizontal line in panel B refers to the amount of biomethane calculated to be produced by anaerobic digestion of the added enzymes. Vertical arrows emphasize the time at which production rate declines to the same or lower as the reference, and the corresponding net biomethane produced at that point, for the respective enzyme. 


\section{Paper III: Enhanced biomethane production rate and yield from lignocellulosic ensiled forage ley by in situ anaerobic digestion treatment with endogenous cellulolytic enzymes}

With lignocellulose being such an important source of bioorganic material for renewable energy much efforts have been directed to improve the release of glucose from lignocellulose for bioethanol and biogas production.

For enzymatic pretreatment for biogas production a large array of various enzymes has been investigated for effect on biogas production, including laccases, peroxidases, cellulases, $\beta$-glucosidases, xylanases and more. However, as for enzyme treatment of WWTP sludge, with very mixed results. In addition, all these pretreatment methods require auxiliary equipment, milling, $\mathrm{pH}$ adjustment etc. Thus, the pretreatments are costly and energy intense. Therefore, it would be attractive if the treatment could be made in situ by directly adding enzymes to the anaerobic digester. However, with almost all commercially available cellulolytic enzymes being derived from aerobic fungi this has a low likelihood to work since these enzymes are not evolutionarily evolved to be active and stable in the anaerobic digester environment (as could also be noted for cellulase in paper II).

Obviously, lignocellulosic material can be, and is, degraded by anaerobic digestion. Thus, members of methanogenic microbial communities are obviously able to produce the necessary lignocellulolytic enzymes for lignocellulose digestion. However, the process is slow, meaning that the retention time for complete digestion would need to be very long. A long retention time means that biogas reactors of very large volume would be needed for complete digestion. If the degradation rate and thereby the retention time could be substantially shortened the turnover and biogas production per volume bioreactor could be increased. That is, if an average retention time of approx. 50 days could be decreased to half, with the same degree of digestion, the biogas production from lignocellulose could be doubled in the same reactor volume.

Thus, it would appear that the microorganisms have the ability to produce the necessary enzymes, but that there is simply not enough of them produced to provide a fast process. To test if addition of higher concentrations of endogenous cellulolytic enzymes can increase the rate of degradation and biogas 
production from lignocellulose a dedicated methanogenic community was used to induce over-expressed cellulolytic enzymes. This enzyme mixture was then added to a batch experiment of ensiled forage ley and compared to an untreated reference.

This approach resulted in a significantly increase in biogas production rate. Interestingly, also the final BMP (at > 100 days) was slightly increased indicating that additional material was released (Figure 10). However, the most important result was that the effect of the added endogenous enzymes remained over the whole time of the experiment until the lignocellulosic substrate was completely digested. Meaning that the enzymes were active not only against the readily accessible components but also on less accessible and recalcitrant material. Thus, showing that the endogenous enzymes were active and stable in the anaerobic digester environment.

This finding indicates that efficient in situ treatment for increased biogas production from lignocellulosic material is possible if the enzymes responsible for the effect could be identified and produced on a larger scale. For this purpose, a parallel work of enzyme discovery was performed with some promising results (Speda et al, 2017). 


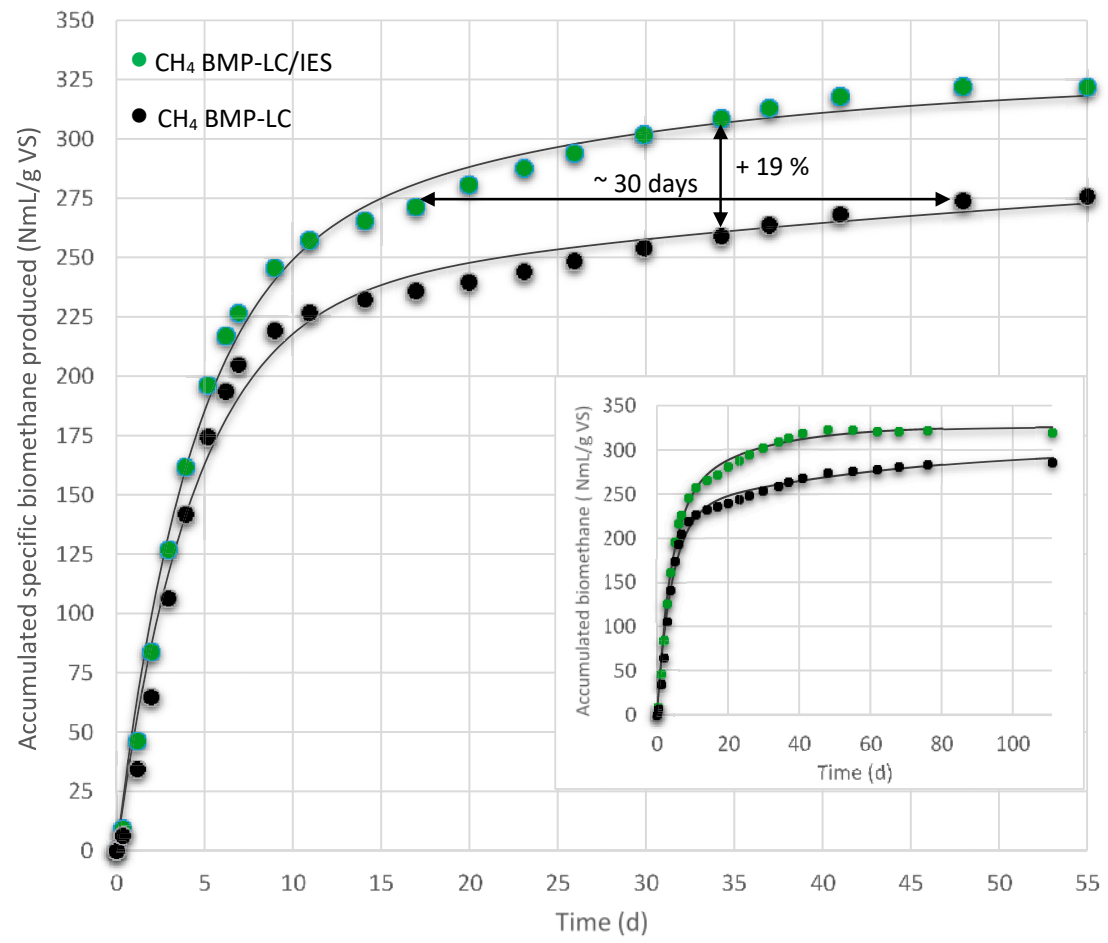

Figure 10- Accumulated specific biomethane produced from ensiled forage ley in the enzyme augmented sample and the untreated reference after subtraction for background production from the untreated inoculum reference. 


\section{Conclusions}

The studies included in this thesis have focused on influencing the early stage of the anaerobic digestion process for increased biogas production from different substrates. The bottom line of the studies presented are:

Addition of zeolites to slaughterhouse waste spiked with long chain fatty acids (LCFA) could relived the inhibitory stress from LCFA. This resulted in that the originally shorter lag phase before biomethane production commenced was restored. The inhibition was caused by LCFA produced during the anaerobic digestion process and not present in the substrate before degradation started, with the LCFA mainly affecting acetate consuming acetoclastic methanogens.

The life time of commercial enzymes were found to be limited in the two WWTP sludge environments due to proteolytic activity of endogenous enzymes. Even though the enzymes had a limited life time in the environments an increased biogas production rate and yield could be observed for some of the selected enzymes, and in particular so for the protease subtilisin.

Cellulolytic enzymes endogenous to a methanogenic microbial community was active and stable in the anaerobic digestion process. Addition of these enzymes to the anaerobic digestion of ensiled forage ley resulted in significantly increased rate and yield of biomethane production. Importantly, the biogas production rate for less accessible lignocellulosic material was also affected upon addition of the enzyme mixture. 


\section{Future prospects}

As shown in paper II and III enzymes can have a significant effect on biogas production rate and yield from specific substrate components. However, for implementing the use of enzymes, better enzymes than what is currently available is needed. In particular enzymes with high stability and long enzymatic activity life time are required.

Naturally present enzymes are adapted to be active and stable in the environment in which they are produced. For example, as shown in paper III, where enzymes derived from a mesophilic anaerobic digester was shown to be active and stable in the anaerobic digestion of lignocellulose. It is therefore of interest to find out more about enzymes adapted to a certain environment and would be a main target for the future research. Alternatively, already promising enzymes, such as subtilisin in paper II, could possibly be engineered to increase stability and resistance to proteolytic digestion.

Thus, according to paper II it would be favorable to identify also novel proteolytic enzymes adapted and stable for anaerobic digestion of WWTP sludge. In fact, this could be a common target for many substrates. Recent research within Linköping university Biogas Research Center (BRC) have provided information that in many cases proteins are poorly digested and that the fraction of protein increases when comparing the ratio of components in the incoming substrate with the outgoing digestate (Shakeri, et al, unpublished data). 


\section{Acknowledgements}

Då var det dags att avsluta detta intressanta projekt. Jag har lärt mig otroligt mycket under tiden på molekylär bioteknik. Jag har fått en inblick i forskning och den akademiska världen och även dragit många lärdomar på ett personligt plan. Jag har flera att tacka för att jag nu står där jag står.

Till att börja med vill jag tacka Martin Karlsson som antog mig som exjobbare på Tekniska Verkens forskningsavdelning för 7 år sedan. Hade vi inte mötts där och då hade jag troligen inte stått där jag står idag, tack!

Tack till Nalle Jonsson som varit ett bra stöd i arbetet och under våra gruppmöten. Du har alltid kommit med konstruktiv feedback!

Till Jutta Speda och Mikaela Johansson, vad skulle jag gjort utan er! Jag hade säkerligen inte klarat det utan er. Bättre kontorskompisar kan man inte få, tack!

Patrik Nygren och Lotta Tolstoy Tegler, tack för er entusiasm och diskussioner vi haft på labbet, grupmöten, runt lunch och fika.

Tack till Susanne Andersson som har varit en klippa när det gäller administrativa frågor och varit en trevlig kollega!

Tack Leffe Johansson för peppande samtal och trevliga pratstunder vid kaffemaskinen eller spektrofotometern!

Tack till torsdagfika gänget i Nalles rum; Martin Karlsson, Nalle Jonsson, Jutta Speda, Mikaela Johansson, Maria Jonson, Linda Helmfors, Therese Klingstedt, 
Liza Bergkvist, Karin Magnusson, Leffe Johansson, Susanne Andersson, Lotta Tolstoy Tegler, Patrik Nygren, Anki Brorson och Rozalyn Simon!

Till deltagarna i projektet inom BRC Mikael Recktenwald, Katarina Stensén, Sören Nilsson Påledal och Bo Svensson tack för hjälp med ideér och tankar gällande experiment upplägg, återkoppling på artiklar etc.

Vår Ivar, livet fick en helt ny innebörd sedan du kom till oss! Jag ser framemot allt vi ska uppleva tillsammans.

Tack till min man Tobias! Du ställer alltid upp oavsett väder! Jag älskar dig. 


\section{References}

Allison S.D., Weintraub M.N., Gartner T.B., Waldrop M.P.. (2011) Evolutionaryeconomic principles as regulators of soil enzyme production and ecosystem. Shukla G, Varma A, (editors). Soil enzymology, soil biology. Berlin, Germany: Springer, 229-243.

Angelidaki, I, Ahring, B.K. (1993). Thermophilic anaerobic digestion of livestock waste: the effect of ammonia. Applied Microbiology and Biotechnology, 38 (4), 560-564.

Angelidaki, I., Ahring, B.K. (1992). Effects of free long-chain fatty acids on thermophilic anaerobic digestion. Applied Microbiology and Biotechnology, 37(6), 808-812.

Arpigny, J.L, Jaeger, K-E. (1999). Bacterial lipolytic enzymes: classification and properties. The Biochemical Journal, 343, 177-183.

Balmér, P. (2013). Avloppsteknik 1, $3^{\text {rd }}$ edition. Balmér, P. Kap. 5 Översikt reningsmetoder. Stockholm, Sweden: Svenskt Vatten, 44-49.

Battimelli, A., Torrijos, M., Moletta, R., Delgenès, J.P. (2010). Slaughterhouse fatty waste saponification to increase biogas yield. Bioresource Technology, 101 (10), 3388-3393.

Benjaminsson, J. (2006). Nya renings- och uppgraderingstekniker för biogas. (Division of energy systems. Linköpings Universitet, SGC, rapport 163). ). Malmö, Sweden: SGC.

http://www.sgc.se/ckfinder/userfiles/files/SGC163.pdf

Bisswanger, H. (2013). Practical Enzymology, $2^{\text {nd }}$ edition. New Jersey, USA: John Wiley \& Sons.

Bryant, M, P. (1979). Microbial methane production- theoretical aspects. Journal of animal science, 48 (1), 193-201.

Buswell, A.M., Mueller, H.F.(1952). Mechanism of methane fermentation. Industrial and Engineering Chemistry, 44 (3), 550-552. 
Carrère, H., Dumas, C., Battimelli, A., Batstone, D.J., Delgenès, J.P., Steyer J.P., Ferrer, I. (2010). Pretreatment methods to improve sludge anaerobic degradability: A review. Journal of hazardous materials, $183(1-3), 1-15$.

Carlsson, M., Uldal, M. (2009). Substrat handbok för biogasproduktion (Rapport SGC 200). Malmö, Sweden: SGC. http://www.biogasjamt land.se/wp-content/uploads/2014/08/SGC-2009-Substrathandbokf\%C3\%B6r-biogasproduktion.pdf

Cavaleiro, A.J., Sousa, D.Z., Alves, M.M. (2010). Methane production from oleate:assessing the bioaugmentation potential of Syntrophomonas zehnderi. Water Reseasrch, 44 (17), 4940-4947.

Chen, Y., J.J. Cheng, Creamer, K.S. (2008).Inhibition of anaerobic digestion process: a review. Bioresource. Technology, 99 (10), 4044-4064.

Christopher, L. P., Yao, B., Ji, Y. (2014). Lignin biodegradation with laccasemediator systems. Frontiers in Energy Research, 2 (12) 1-13.

Christy, P.M., Gopinath, L.R., Divya, D. (2014). A review on anaerobic decomposition and enhancement of biogas production through enzymes and microorganisms. Renewable and Sustainable Energy Reviews, 34, 167-173.

Cirne, D.G., Paloumet, X., Björnsson, L., Alves, M.M., Mattiasson, B. (2007).Anaerobic digestion of lipid-rich wasted-Effects of lipid concentration. Renewable Energy, 32 (6), 965-975.

Cragg, S.M., Beckham G.T., Bruce N.C., Bugg T.D., Distel D.L., Dupree P., Etxabe A.G., Goodell B.S., Jellison J., McGeehan J.E., McQueen-Mason S.J., Schnorr K., Walton P.H., Watts J.E., Zimmer M.. (2015). Lignocellulose degradation mechanisms across the tree of life. Current Opinion in Chemical Biology. 29, 108-119

Davidsson, Å., Lövstedt, C., la Cour Jansen, J., Gruvberger, C., Aspegren, H. (2008). Codigestion of grease trap sludge and sewage sludge. Waste Management, 28 (6), 986-992.

Demirel, B., Scherer, P. (2008).The roles of acetotrophic and hydrogenotrophic methanogens during anaerobic conversion of biomass to methane: a review. Reviews in Environmental Science Bio/ Technology,7 (2), 173-190.

Deublein, D., Steinhauser, A. (2008). Biogas from waste and renewable resources and introduction. Weinheim, Germany: Wiley-Vch Verlag GmbH Co. 
Dey, E.S., Szewczyj, E., Wawrynczyk, J., Norrlow, O. (2006). A novel approach for Charicterization of exopolymeric material in sewage sludge. Journal of Residuals Science and Technology, 3 (2), 97-103.

Donso-Bravo, A., Pérez-Elvira, S., Aymerich, E., Fdz-Polanco, F., (2011).Assesment of the influence of thermal pre-treatment time on the molecular composition and anaerobic biodegradabililty of sewage. Bioresource Technology, 102 (2), 660-666

Klackenberg, L.(2018). Energigas Sverige.http://www.biogasportalen.se/FranRavara TillAnvandning/Anvandning.aspx (accessed 04 06, 2018).

Eriksson, E., Harrysson, J. (2017). Produktion och användning av biogas och rötrester år $2016 \quad$ ES 2017:07, Eskilstuna, Sweden :Energimyndigheten

http://www.energigas.se/library/1955/produktion-och-anvaendningav-biogas-och-roetrester-aar-2016.pdf

EuroObserv'ER biogas barometer: http://eurobserv-er.org/biogas-barometer-2014/ (accessed 04,06, 2018)

Eurostat, 2016, http://ec.europa.eu/eurostat/web/environment/waste (accessed 04,06,2018)

Gerardi, Michael H. (2003).The Microbiology of Anaerobic Digesters. Hoboken, USA: John Wiley \& Sons, 73-76.

Girault, R., Bridoux, G., Nauleau, F., Poullain, C., Buffet, J., Peu, P., Sadowski, A.G.,Béline, F. (2012). Anaerobic co-digestion of waste activated sludge and greasy sludge from flotation process: batch versus CSTR experiments to investigate optimal design. Bioresource Technology, 105, 1-8.

Gossett, J.M., Belser, R.L.(1982). Anaerobic-digestion of waste activated sludge. Journal Environmental Engineering, 108, 1101-1120.

Hanaki, K., Nagase, M. (1981).Mechanism of Inhibition Caused by Long-Chain Fatty Acids in Anaerobic Digestion Process. Biotechnology and Bioengineering, 23(7), 1591-1610.

Hashimoto, A.G. (1986). Ammonia inhibition of methanogenesis from cattel wastes. Agricultural Wastes, 17 (4), 241-261

Hatamoto, M., Imachi, H., Fukayo, S., Ohashi, A., Harad, H. (2007). Syntrophomonas palmitatica sp. nov., an anerobic, syntrophic, long-chain fatty-acids-oxidizing bacterium isolated from methanogenic sludge. International Journal of systematic and evolutionary microbiology, 57, 2137-2142. 
Hendriks, A.T.W.M., Zeeman, G. (2008). Pretreatments to enhance the digestibility of lignocellulosic biomass. Bioresource Technology, 100 (1), 10-18

Kayhanian, M. (1994). Performance of a high-solids anaerobic digestion process under various ammonia concentrations. Journal of Chemical Technology and Biotechnology, 59 (4), 349-352.

Jackson, B.E., Bhupathiraju, V.K., Tanner, R.S., Woese, C.R., McInerney, M.J. (1999). Syntrophus aciditrophicus sp. nov., a new anaerobic bacterium that degrades. Archives of microbiology, 171 (2), 107114.

Jonsson, S., Borén, H. (2002). Analysis of mono- diesters of o-phthalic acid by solid-phase extractions with polystyrene divinylbenzene based polymers. Journal of chromatography A., 963, 393-400.

Khanal, S. (2008). Anaerobic Biotechnology for Bioenergy Production. Microbiology and Biochemistry of Anaerobic Biotechnology. Singapore: Wiley-Blackwell, 29-41.

Koster, I., W., Cramer, A. (1987). Inhibition of Methanogenesis from Acetate in Granular Sludge by Long-Chain Fatty Acids. Applied and environmental microbiology, 53 (2), 403-409.

Kudanga, T., Le Roes-Hill, M. (2014). Laccase application in biofuels production:current status and future prospects. Applied Microbiology and Biotechnology, 98 (15), 6525-6542.

Lakowicz, J.R., (2006). Principles if Fluorescence Spectroscopy, $3^{\text {rd }}$ edition. Berlin, Germany: Springer.

Lalman, J., Bagley, D.M. (2002). Effects of C18 long chain fatty acids on glucose, butyrate and hydrogen degradation. Water Research, 36 (13), 33073313.

Lalman, J.A., Bagley, D.M. (2000). Anaerobic degradation and inhibitory effects of linoleic acid. Water Research, 34 (17), 4220-4228.

Lalman, Jerald, A., Bagley, D.M. (2001). Anaerobic digestion and methanogenic inhibitory effects of oleic and stearic acid. Water Research. 35 (12), 2975-2983.

Luostarinen, S., Luste, S., Sillanpää, M. (2009). Increased biogas production at wastewater treatment plants through co-digestion of sewage sludge with grease trap sludge from a meat processing plant. Bioresource Technology, 100 (1), 79-85.

Madigan, M., Martinko, J. (2006). Brock Biology of Microorganism. Madigan, M.T., Martinko, J.M, Chap. 12. New Jersey, USA: Pearson Benjamin Cummings 329-419. 
Moiser, N., Wyman, C., Dale, B., Elander, R., Lee, Y.Y., Holtsapple, M., Ladisch, M. (2005). Features of promising technologies for pretreatment of lignocellulosic biomass. Bioresource Technology, 96 (6), 673-686

Müller, G., Várnai, A., Johansen, K.S., Eijsink, V.G.H., Horn, S.J. (2015). Harnessing the potential of LPMO-containing cellulase cocktails poses new demands on processing conditions. Biotechnology for biofuels, 8 (187), 1-9

Mussatto, S.I. (2016). Biomass fractionation technologies for lignocellulosic feedstock based refinery. New York, USA: Elsevier. Inc.

Naturvårdsverket (2014). Rening av avloppsvatten i Sverige 2014. ISBN 978-91620-8728-9,

http://www.naturvardsverket.se/Documents/publikationer6400/97891-620-8629-9.pdf.

Nordell, E., Hallin, S., Johansson, M., Karlsson, M. (2010). The diverse response on degradation of different substrates upon addition of zeolites. 2010. In: 3rd International Symposium on Energy from Biomass and Waste. Venice, Italy, Nov 8-11, 2010.

Nordell. E. (2009). Effects of Zeolites in the Production of Biogas. Master Thesis

Noutsopoulos, C., Mamais, D., Antoniou, K., Avramides, C., Oikonomopoulos, P., Fountoulakis, I. (2013). Anaerobic co-digestion of grease sludge and sewage sludge: the effect of organic loading and grease sludge content. Bioresource Technology, 131, 452-459.

Nybroe, O., Jörgensen, ,P.E., Henze, M. (1992). Enzyme activites in wastewater and activated sludge. Water research, 26 (5), 579-584

Palatsi, J., Viñas, M., Guivernau, M., Fernandez, B., Flotats, X. (2011). Anaerobic digestion of slaughterhouse waste: main process limitations and microbial community interactions. Bioresource Technology, 102(3), 2219-2227.

Parawira, W. (2012). Enzyme research and applications in biotechnological intensification of biogas production. Critical Reviews in Biotechnology, 32 (2), 172-186

Parmar, N., Singh, A., Ward, O.P. (2001). Enzyme treatment to reduce solids and improve settling of sewage sludge. Journal of industrial microbiology and biotechnology, 26 (6), 383-386.

Pereira, M.A., Pires, O.C., Mota, M., Alves, M.M. (2005). Anaerobic biodegradation of oleic and palmitic acids: evidence of mass transfer limitations 
caused by long chain fatty acid accumulation onto the anaerobic sludge. Biotechnology Bioengineering, 92 (1), 15-23.

Pind, P., F., Angelidaki, I., Ahring, B.K., Stametelatou, K., Lyberatos, G. (2003). Monitoring and control of anaerobic reactors. Advances Biochemical Engineering/Biotechnology, 82, 137-179

Pollegioni, L., Tonin, F., Rosini, E. (2015). Ligning-degrading enzymes. The FEBS Journal, 282, 1190-1213

Ramsay, I.R., Pullammanappallil, P.C. (2001). Protein degradation during anaerobic wastewater treatment: derivation of stoichiometry. Biodegradation, 12 (4), 247-257.

Rinzema, A., Boone, M., van Knippenberg, K., Lettinga, G. (1994). Bactericidal effect of long-chain fatty acids in anaerobic digestion. Water Environment Research, 66 (1), 40-49.

Roy, F., Albagnac, G., Samain, E. (1985). Influence of Calcium Addition on Growth of Highly Purified Syntrophic Cultures Degrading Long-Chain Fatty Acids. Applied and environmental microbiology, 49, 702-705.

Salminen, E., Rintala, J. (2002 a). Anaerobic digestion of organic solid poultry slaughterhouse waste- a review. Bioresource Technology, 83 (1), 13-26.

Salminen, E.and Rintala, J. (2002 b). Semi-continuous anaerobic digestion of solid poultry slaughterhouse waste: effect of hydraulic retention time and loading. Water Research, 36 (13), 3175-3182.

Schnürer, A., Jarvis, ̊. (2009). Mikrobiologisk handbok för biogasanläggningar. Rapport U2009:03, Malmö, Sweden: Svenskt gastekniskt centrum $\mathrm{AB}$.

Schnürer, A., Zellner, G.,, Svensson, H., B. (1999). Mesophilic syntrophic acetate oxidation during methane formation in biogas reactors. Fems Microbiology ecology, 29 (3), 249-261.

Sousa, D.Z., Smidt, H., Alves, M.M., Stams, A.J.M. (2007). Syntrophomonas zehnderi sp. nov., an anaerobe that degrades long-chain fatty acids in co-culture with Mehanobacterium formicicum. International Journal of systematic and evolutionary microbiology, 57 (3), 609615.

Sousa, D.Z., Smidt, H., Alves, M.M., Stams, A.J.M. (2009). Ecophysiology of syntrophic communities that degrade saturated and unsaturated long-chain fatty acids. FEMS Microbiolgy Ecology, 68 (3), 257-272

Speda, J., Johansson, M., Jonsson, B.H., Karlsson, M. (2016). Applying therories of microbial metabolism for induction of targeted enzyme activity in a 
methanogenic microbial community at a metabolic steady state. Applied Microbiology and Biotechnology. 100 (18), 7989-8002

Speda, J., Jonsson, B-H., Carlsson, U., Karlsson, M. (2017). Metaproteomics-guided selection of targeted enzymes for bioprospecting of mixed microbial communities. Biotechnology for Biofuels, 10, 128.

Sprott, G.D., Shaw, K.M., Jarrel, K.F.(1984). Ammonia/potassium exchange in methanogenic bacteria. Journal of Biological Chemistry, 259, 12602-12608.

Sprott, G.D., Patel, G.B. (1986). Ammonia toxicity in pure cultures of methanogenic bacteria. Systematic and Applied Microbiology, 7 (2-3), 358-363

Sundin, A.-M., Linderholm, L., Hedlund, B., Joyce, K., Klingspor, K. (2017). Avancerad renings av avloppsvatten för avskiljning av läkemedelsrester och andra oönskade ämnen-behov, teknik och konsekvenser 6766, Naturvårdsverket, Stockholm, Sweden:Naturvårdsverket.

https://www.naturvardsverket.se/Documents/publikationer6400/978 -91-620-6766-3.pdf?pid=20525

Tanaka, S., Kobayashi, T., Bildan, M. (1997). Effects of thermochemical pretreamtnet on the anaerobic digestion of waste activated sludge. Water Science Technology, 35 (8), 209-215

van Velsen, A.F.M. (1979). Adaptation of methanogenic sludge to high ammonianitrogen concentrations. Water Research, 13 (10), 995999.

Wan, C., Zhou, Q., Fu, G., Li, Y. (2011). Semi-continuous anaerobic co-digestion of thickened waste activated sludge and fat, oil and grease. Waste Management, 31(8), 1752-1758.

Wang, L., Aziz, T.N., de los Reyes, F.L. (2013). Determining the limits of anaerobic codigestion of thickened waste activated sludge with grease interceptor waste. Water Research, 47 (11), 3835-3844.

Vavilin, V.A., Fernandez, B., Palatsi, J., Flotats, X. (2008). Hydrolysis kinetics in anaerobic degradation of particulate organic material: an overview. Waste Management, 28 (6), 939-951.

Weng, C.-N., Jeris, J.S. (1976). Biochemical mechanisms in the methane fermentationof glutamic and oleic acids. Water Research, 10 (1), 9-18.

Westerholm, M., Hansson, M., Schnürer, A. (2012). Improved biogas production from whole stillage by co-digestion with cattle manure. Bioresource Technology, 114, 314-319. 
Wilson, C.A., Novak, J.T. (2009). Hydrolysis of macromolecular components of primary and secondary wastewater sludge by thermal hydrolytic pretreatment. Water Research, 43 (18), 4489-4498.

Wu, C., Dong, X., Liu, X. (2007). Syntrophomonas wolfei subsp. methylbutyratica subsp. nov., and assignment of Syntrophomonas wolfei subsp. saponavida to Syntrophomonas saponavida sp. nov. comb. nov. Systematic and Applied Microbiology, 30 (5), 376-380.

Zinder, Stephen, H. (1984). Microbiology of anaerobic conversion of organic wastes to methane: recent developments. ASM News, 50 (7), 294-298. 


\section{Papers}

The papers associated with this thesis have been removed for copyright reasons. For more details about these see:

http://urn.kb.se/resolve?urn=urn:nbn:se:liu:diva-147721 